\title{
WHY IS WORKPLACE SEXUAL HARASSMENT UNDERREPORTED? THE VALUE OF OUTSIDE OPTIONS AMID THE THREAT OF RETALIATION
}

\author{
Gordon B. Dahl \\ Matthew M. Knepper \\ Working Paper 29248 \\ http://www.nber.org/papers/w29248 \\ NATIONAL BUREAU OF ECONOMIC RESEARCH \\ 1050 Massachusetts Avenue \\ Cambridge, MA 02138 \\ September 2021
}

We are grateful to Ron Edwards and the EEOC for their guidance and provision of the EEOC microdata. We thank colleagues and seminar participants at several universities and conferences for valuable feedback and suggestions. The views expressed herein are those of the authors and do not necessarily reflect the views of the National Bureau of Economic Research.

NBER working papers are circulated for discussion and comment purposes. They have not been peer-reviewed or been subject to the review by the NBER Board of Directors that accompanies official NBER publications.

(C) 2021 by Gordon B. Dahl and Matthew M. Knepper. All rights reserved. Short sections of text, not to exceed two paragraphs, may be quoted without explicit permission provided that full credit, including $\odot$ notice, is given to the source. 
Why is Workplace Sexual Harassment Underreported? The Value of Outside Options Amid the Threat of Retaliation

Gordon B. Dahl and Matthew M. Knepper

NBER Working Paper No. 29248

September 2021

JEL No. J71,J78

\begin{abstract}
Why is workplace sexual harassment chronically underreported? We hypothesize that employers coerce victims into silence through the threat of a retaliatory firing, and test this theory by estimating whether external shocks that reduce the value of a worker's outside options exacerbate underreporting. Under mild assumptions, a rise in the severity of formal complaints is indicative of increased underreporting. Combining this insight with an objective measure of the quality of charges filed with the Equal Employment Opportunity Commission (EEOC), we perform two analyses. First, we assess whether workers report sexual harassment more selectively during recessions, when outside labor market options are limited. We estimate the fraction of sexual harassment charges deemed to have merit by the EEOC increases by $0.5-0.7 \%$ for each one percentage point increase in a state-industry's monthly unemployment rate. The effect is amplified in industries employing a larger fraction of men and in establishments with a higher share of male managers. Second, we test whether less generous UI benefits create economic incentives for victims of workplace sexual harassment to remain silent. We find the selectivity of sexual harassment charges increases by more than $30 \%$ in response to a $50 \%$ cut to North Carolina's Unemployment Insurance (UI) program following the Great Recession.
\end{abstract}

Gordon B. Dahl

Department of Economics

University of California, San Diego

9500 Gilman Drive \#0508

La Jolla, CA 92093-0508

and NBER

gdahl@ucsd.edu

Matthew M. Knepper

Terry College of Business

University of Georgia

Athens, GA 30602

mknepper@uga.edu 
Virtually all of the people I spoke with told me that they were frightened of retaliation. "If Harvey were to discover my identity, I'm worried that he could ruin my life," one former employee said.

- "From Aggressive Overtures to Sexual Assault: Harvey Weinstein's Accusers Tell Their Stories," The New Yorker, October 23, 2017

\section{Introduction}

Based on anonymous survey responses, no fewer than 1 in 28 U.S. workers report having been victimized by workplace sexual harassment annually. ${ }^{1}$ Yet only 1 in 11,000 workers file a formal sexual harassment charge with the Equal Employment Opportunity Commission (EEOC), the agency tasked with enforcing all federal anti-discrimination laws. Even in the aftermath of the \#MeToo-induced reckoning, harassment charges are up only 10\%, not nearly sufficient to close the underreporting gap. A major concern with underreporting is that it exacerbates the behavior: faced with a low probability of punishment, firms may respond by pushing the boundaries of their misconduct further.

The costs of this hidden sexual harassment, which affect an estimated 5 million workers per year, are substantial. Prior evidence suggests that victimization leads to a steep loss in job satisfaction, elevated emotional and mental stress, declines in productivity, increases in absenteeism, and job turnover. ${ }^{2}$ To give a sense of the magnitude of these costs, Hersch (2018) estimates the value of statistical harassment (VSH) for serious cases at approximately $\$ 7.6$ million, which is roughly comparable to the value of a statistical life (VSL). This figure does not include pre-market costs of avoiding sexual harassment, which one study estimates to be $20 \%$ of the present discounted value of lifetime earnings in India (Borker, 2017).

Why is it, then, that underreporting is so common? One candidate explanation is

\footnotetext{
${ }^{1}$ These calculations come from the the 2015 American Working Conditions Survey conducted by Maestas et al. (2017). The General Social Survey (see McCann et al., 2018) and the 2018 National Study on Sexual Harassment and Assault yield similar findings. The EEOC estimates that conditional on being harassed in the workplace, $75 \%$ of victims do not report (Feldblum and Lipnic, 2016).

${ }^{2}$ See Merit (1981); Crull (1982); Fitzgerald et al. (1988, 1994); Gutek (1985); Acken et al. (1991); Frierson (1989); Gutek and Koss (1993); Faley et al. (1994); Laband and Lentz (1998).
} 
that firms and managers coerce their employees into silence through the threat of retaliation - through a firing, wage cut, or assignment to undesirable tasks or schedules - for engaging in a "protected activity," such as filing a charge with the EEOC. Figure 1 demonstrates that not only is employer retaliation a common response to an employee's decision to file a sexual harassment charge, but that this behavior has become increasingly common over time, rising from $52 \%$ of cases in 2000 to $72 \%$ in 2015 . At the same time, the number of annually filed sexual harassment charges has fallen by $37 \%$. Viewed in isolation, this latter pattern could naively be construed as a sign that the problem of workplace sexual harassment has diminished over time. A more cynical interpretation is that firms have become more adept at credibly wielding the threat of retaliation to suppress worker reports. While the fear of employer retaliation has been hypothesized as a possible explanation for underreporting of sexual harassment, it has not formally been tested (Berrey et al., 2017; Stainback and Tomaskovic-Devey, 2012; Knapp et al., 1997). ${ }^{3}$ One reason is that it is difficult to measure what is not reported.

We overcome this challenge by recognizing that external forces which reduce the value of becoming unemployed should increase the employee's cost of a retaliatory firing, thus raising the threshold above which a victim is willing to file a charge. If workers become more selective about the degree of sexual harassment they are willing to endure before breaking their silence, this implies that underreporting must be rising. The identifying assumption is that a worker's willingness to file a sexual harassment claim depends only on her outside options and the severity of sexual harassment she experiences. ${ }^{4}$ There is not a clear prediction about how the volume of reported claims responds, as this would require assumptions about firm behavior.

We measure the quality/selectivity of sexual harassment charges using the EEOC's de-

\footnotetext{
${ }^{3}$ Consistent with this explanation, but for a different outcome, Johnson et al. (2020) show that serious injuries fall by $12 \%$ in states that enacted whistleblower protections in the 1970 s and 1980 s. Boone et al. (2011) find that workers who report workplace accidents are subsequently more likely to be fired.

${ }^{4}$ In our empirical work, we only require this assumption to hold conditionally, that is, after netting out state, industry, and time fixed effects.
} 
termination of whether a case has merit. We use this to test whether victims become increasingly reluctant to jeopardize their current employment when the value of their outside options diminishes. ${ }^{5}$ The merit variable captures the quality of a case as long as the EEOC applies a consistent standard for determining merit, at least after netting out state, industry, and time fixed effects.

Our first analysis exploits variation over time in a state-industry's unemployment rate. Using data from 2000-2015, we find that each 1 percentage point rise in the unemployment rate increases the probability a charge is determined to have merit by $0.5-0.7 \%$. This is consistent with the hypothesis that a weakened outside labor market leads more victims to remain silent for fear of retaliation.

We interpret this increase in the quality of filed charges more formally through the lens of a threshold model of reporting. In this model, workers choose a level of harassment they are willing to tolerate, above which they will file an EEOC charge. This threshold value increases as outside job opportunities worsen. Hence, the response by victims to a decline in labor market prospects is to increase the selectivity of charges they file.

We extend this analysis by documenting facts and providing insights into possible mechanisms. To do this, we link the EEOC charge data with information on the gender mix of managers and co-workers within establishments. We show that reporting increases in the fraction of male colleagues, consistent with related findings from Folke and Rickne (2020). Unlike Folke and Rickne (2020), we also find that reporting increases when a larger fraction of men occupy supervisory roles. We go one step further and show that underreporting, as proxied by selectivity, increases in both the fraction of male managers and male co-workers. The male-manager underreporting gradient is amplified by a higher unemployment rate. These results highlight the prominent role of power disparities that run along gender lines.

Our second analysis takes advantage of a plausibly exogeneous change in the generosity of North Carolina's unemployment insurance (UI) program. Since UI partially protects workers

\footnotetext{
${ }^{5}$ This hypothesis is also consistent with Lazear et al. (2016), who show that worker effort is positively correlated with local unemployment rates during the Great Recession.
} 
from income loss in the event of a retaliatory firing, it follows that reductions in UI generosity may stifle reporting behavior. In the aftermath of the Great Recession, North Carolina addressed the looming insolvency of its state UI fund by slashing the maximum weekly benefits available by $35 \%$ (from $\$ 535$ to $\$ 350$ ), reducing the duration over which recipients could receive benefits from 26 to 20 weeks, and imposing additional eligibility restrictions. ${ }^{6}$ Consistent with our hypothesis, we find that the selectivity of sexual harassment charges filed in North Carolina subsequently rose by 7 percentage points, representing more than a

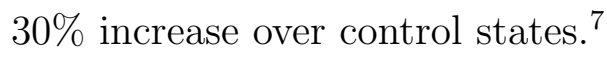

Our paper contributes to a nascent literature in economics inspired by the \#MeToo movement. Cheng and Hsiaw (2020) develop a theoretical model of reporting sexual harassment in the workplace, where underreporting occurs due to uncertainty about whether other victims within the firm will corroborate patterns of sexual misconduct. Folke and Rickne's (2020) study of sexual harassment and firm gender ratios uses information collected via an anonymous survey, which means there are no labor market consequences for the respondents. We add to their work by underscoring how the incentives of employees to report sexual harassment to authorities depend on potential economic costs. ${ }^{8}$ Finally, Sockin et al. (2021) study changes in non-disclosure agreement (NDA) laws designed to protect trade secrets, but which have also been used to restrict workers from disclosing negative information about firm practices. They find that less restrictive NDA laws decrease employee ratings of the firm, and increase the fraction of reviews mentioning words related to bullying or harassment (but not necessarily sexual harassment). Our paper provides a novel way to

\footnotetext{
${ }^{6}$ These combined changes violated the U.S. Congress' non-reduction rule, and made individuals ineligible for the additional 47 weeks of UI benefits provided through the federal Emergency Unemployment Compensation (EUC) program.

${ }^{7}$ We note that North Carolina also reduced corporate and personal income taxes shortly after the UI reform. This tax reform should have increased labor demand and increased labor supply (as long as substitution effects dominate income effects), and so we interpret our estimates as lower bounds of the effect of the UI reform on selectivity.

${ }^{8}$ Consistent with this idea, Grittner and Johnson (2020) show that the Secure Communities immigration enforcement program reduces Hispanic workers' willingness to file complaints about poor working conditions and subsequently raises injury rates. In a non-workplace setting, Levy and Mattsson (2019) show that sexual harassment reporting to the police increases in response to the \#MeToo social movement.
} 
demonstrate that increases in retaliation costs suppress the willingness of sexual harassment victims to speak out, and that this silencing effect is amplified by gendered power disparities within the workplace.

We also contribute to the literature on the effects of unemployment insurance. Whereas previous research focuses primarily on the effects of UI generosity on job search behavior and unemployment spells for those who have already lost their jobs, less research has concerned itself with ex-ante moral hazard effects on those who are currently employed. ${ }^{9}$ One exception is Lusher et al. (2020), which finds that UI expansions during the Great Recession reduced productivity among currently employed supermarket cashiers and increased shirking behavior more broadly. The effects we find are consistent with such ex-ante moral hazard effects, which materialize in our setting as a reduction in the willingness to report sexual harassment when the generosity of UI benefits falls. While Lusher et al. (2020) shows a negative consequence of UI extensions, we document a positive effect.

The remainder of the paper proceeds as follows. We first provide institutional background on the EEOC's role in curbing sexual harassment and on North Carolina's cuts to its UI program. In Section 3, we detail the various data sources we use to study workplace sexual harassment. Section 4 provides a simple threshold model of sexual harassment reporting. In Section 5 we detail the identification strategies used to test how diminished outside options affect sexual harassment underreporting. Section 6 shows results on sexual harassment underreporting based on economic conditions and gendered power disparities, Section 7 details how the selectivity of charges responds to reductions in UI generosity, and Section 8 concludes.

\footnotetext{
${ }^{9}$ See, for example, Moffitt (1985); Katz and Meyer (1990); Christofides and McKenna (1996); Baker and Rea Jr (1998); Card and Levine (2000); Rothstein (2011); Marinescu (2017); Johnston and Mas (2018); Farber and Valletta (2015); Farber et al. (2015); Schmieder and Von Wachter (2016); Marinescu and Skandalis (2021).
} 


\section{Institutional and Policy Background}

\subsection{The EEOC's Enforcement of Illegal Sexual Harassment}

The EEOC defines illegal sexual harassment in the workplace as:

...unwelcome sexual advances, requests for sexual favors, and other verbal or physical harassment of a sexual nature. Harassment does not have to be of a sexual nature, however, and can include offensive remarks about a person's sex. For example, it is illegal to harass a woman by making offensive comments about women in general.

This definition corresponds to the four types of sexual harassment previously identified as standard in the literature (Fitzgerald et al., 1999; Till, 1980; Folke and Rickne, 2020). These include sexist hostility, the expression of insulting or degrading attitudes about men or women, sexual hostility, defined as the use of non-physical behavior such as lewd sexual comments or revealing body parts, sexual coercion, the implicit or explicit trades of sexual favors in exchange for rewards or to avoid punishments, and unwanted sexual attention, which covers inappropriate touching all the way through groping and sexual assault.

For harassment to rise to the level of illegality according to the EEOC, it must be "so frequent or severe that it creates a hostile or offensive work environment or when it results in an adverse employment decision (such as the victim being fired or demoted)." ${ }^{10}$ Meritorious charges, as determined by the EEOC, will have met this "hostile work environment" standard, while non-meritorious charges may still involve some level of harassment without having exceeded the standard. In this sense, the merit designation captures more serious or repeated incidents of sexual harassment. The EEOC assigns a merit designation to a case if either the company settles with the employee, the claimant withdraws their case upon the receipt of benefits, or the EEOC makes a determination that the case has reasonable cause following a lengthy legal investigation. For more details on how charges are resolved, see Dahl and Knepper (2020).

\footnotetext{
${ }^{10}$ See https://www.eeoc.gov/sexual-harassment.
} 
An employee must file a charge within 180 calendar days of the offense either online, by mail, or in person at an EEOC office. Within 10 days of the receipt of the charge, the EEOC sends a notice of the charge to the named employer. While an employee may elect to have another individual or agency file a charge on her behalf, the nature of the process makes it difficult for a victim's anonymity to be preserved. Indeed, the fact that retaliation-which the EEOC defines as punishment for engaging in a protected activity, such as filing a chargearises in over $63 \%$ of all sexual harassment cases makes clear that an individual's identity is not generally protected.

\subsection{Cuts to North Carolina's UI Program}

From the late 1960s through early 2011, all 50 states and DC paid regular unemployment insurance benefits to eligible recipients for at least 26 weeks (McHugh and Kimball, 2015). However, in 2011, unemployment trust funds neared insolvency in a number of states amid record benefit payouts during the protracted recovery from the Great Recession. In response to this deepening crisis, 8 states passed restrictive legislation that permanently cut the number of weeks available through regular UI below this long-established norm of 26 weeks $(\mathrm{GAO}, 2015) \cdot{ }^{11}$

In no state were cuts more draconian than in North Carolina, which was the only one to contemporaneously reduce its maximum weekly benefits (by nearly $35 \%$ from $\$ 535$ to $\$ 350$ per week) while also reducing the maximum allowable benefit weeks available from 26 to $20 .^{12}$ The combined effect of these cutbacks was substantial. The maximum level of regular state-level UI benefits available to North Carolinians fell by 50\%, from approximately $\$ 14,000$ to $\$ 7,000$. These changes violated the Congressional non-reduction rule, which made individuals ineligible for the additional 47 weeks of federally-provided UI benefits.

\footnotetext{
${ }^{11}$ These states are Arkansas, Florida, Georgia, Kansas, Michigan, Missouri, North Carolina, and South Carolina.

${ }^{12}$ Following the reform, maximum duration drops to 12 weeks when the state UR rate is less than $5.5 \%$, and increases by 1 week for each $0.5 \%$ increase until reaching 20 weeks once the UR reaches $9 \%$. North Carolina also restricted access to the program by disqualifying individuals who had lost a job for "good cause," such as providing family caregiving. The waiting period was also increased.
} 
This policy environment is ideal for four related reasons. First, the North Carolina cuts were made on the basis of insolvency issues surrounding its state UI fund, rather than on local labor market conditions. This is in contrast to state Extended Benefits (EB) and federal Emergency Unemployment Compensation (EUC) programs, which use explicit thresholds of the state unemployment rate or insured unemployment rate to determine the duration of eligibility for UI benefits (Marinescu, 2017; Farber and Valletta, 2015). Unlike many previous studies, we are able to estimate discrete changes in UI generosity when the labor market was recovering rather than languishing. Thus, our estimates are unlikely to be driven by an expectation of further deterioration of labor market conditions, rather than a reluctance to report.

Second, these cuts were unique in that they were implemented at a time of historically high unemployment. Thus, the strength of the social safety net was a particularly relevant consideration for those considering actions that might jeopardize current employment.

Third, North Carolina's cuts were large and affected both the intensive and extensive margin of benefits. The cuts were so draconian that between April and July of 2013, thousands of protesters organized at the state capitol in Raleigh each Monday (referred to as "Moral Mondays") to voice their disapprobation. ${ }^{13}$ Unlike the EUC and EB programs analyzed in past work, the North Carolina cuts affected not just duration and generosity (i.e., the intensive margin) but also reduced eligibility (the extensive margin). Extensive margin cuts are likely to be particularly salient for women worried about a retaliatory firing. ${ }^{14}$

Fourth, North Carolina's UI reductions were permanent and affected the first source of benefits from which individuals claiming UI draw. Only after exhausting regular UI benefits are individuals eligible for EB and EUC. Thus, access to regular state UI benefits is relatively more valuable as they are discounted less heavily.

One caveat is that North Carolina also reduced corporate and personal income taxes soon

\footnotetext{
${ }^{13}$ See https://www.usatoday.com/story/news/nation/2013/07/21/north-carolina-unemployment/2571889/.

${ }^{14}$ Prior research has shown that currently employed workers' labor supply is responsive to changes in UI generosity (Light and Omori, 2004). Christofides and McKenna (1996); Baker and Rea Jr (1998) document employment responses on the extensive margin of UI eligibility.
} 
after the UI reform. However, this tax reform should have increased both labor demand and labor supply (as long as substitution effects dominate income effects), and so we interpret our estimate as a lower bound of the effect of the UI reform.

In spite of the many advantages of studying changes to UI generosity generated from legislative rollbacks, there is limited research leveraging this variation. A notable exception is Johnston and Mas (2018), which finds a benefit cut in Missouri reduced unemployment

spells and moderately reduced the state's overall unemployment rate. In ongoing work, we study the effect of North Carolina's reform on starting salaries and other labor market outcomes. We find that starting salaries fall sharply following the reform relative to control states.

\section{Data and Sample Construction}

This paper leverages several novel data sources to provide a uniquely detailed view of workplace sexual harassment. We combine data on the quality (and volume) of individual sexual harassment reports filed with the EEOC with three data sources to study how economic conditions, workplace characteristics, and social safety net programs each influence incentives for victims to report. First, we impute contemporaneous estimates of local labor market conditions with data produced by the Bureau of Labor Statistics (BLS). We also link the charge data to the EEO-1 files collected by the EEOC, which detail the racial, gender, and occupational distribution of workers in private establishments. Lastly, we link the charge data with publicly available information on the timing and severity of the cut to North Carolina's UI program.

\subsection{EEOC Charge Data}

Our study draws on the universe of all sexual harassment charges filed with the EEOC between 2000 and 2015, which is the most comprehensive and authoritative data source 
on workplace sexual harassment in the United States. These data are an improvement over measures of discrimination that are commonly used in the economics literature, such as wage and employment gaps, which only obliquely capture potential discrimination. The EEOC data, in contrast, directly measure on-the-job sexual harassment.

Moreover, these EEOC data include the resolution associated with each charge, which reveals whether the EEOC determined that the charge had reasonable cause. This merit variable then serves as a proxy for the quality of each sexual harassment charge filed, allowing us to test whether individuals become more selective about reporting. While a few others have used these or the nationally aggregated version of these data to study sexual harassment in the United States (Hersch, 2011, 2018; McCann et al., 2018; Cassino and Besen-Cassino, 2019), they have focused on the volume of charges virtually to the exclusion of merit considerations.

Table 1 provides several pieces of evidence that highlight just how widespread the underreporting problem is, and a hint for the mechanism. Based on all charges filed between 2000 and 2015, we find that, compared to non-harassment charges, sexual harassment charges are nearly $50 \%$ more likely to have been meritorious (27.0\% versus $18.6 \%)$ and more than twice as likely to have involved employer retaliation (63.4\% versus $30.7 \%$ ) and employer intimidation $(5.7 \%$ versus $2.7 \%)$. These differences accord with earlier work from a survey of public employees showing that $75 \%$ of those who report sexual harassment face retaliation (Cortina and Magley, 2003). As further evidence that sexual harassment cases are more egregious discrimination filings on average, they are nearly $65 \%$ more likely to have private legal representation compared to all other charges (13.0\% compared to $7.9 \%$ ).

The table also shows that $84 \%$ of sexual harassment complainants are female (compared to $52 \%$ of non-sexual harassment victims), and they are younger than their non-harassed counterparts. Sexual harassment victims are overrepresented in Accommodation \& Food Services as well as in Retail. 


\subsection{State and Industry Unemployment Data}

We measure local variation in the number of unemployed individuals at the state-month level using BLS Local Area Unemployment Statistics (LAUS). To impute local variation at the state-industry-month level, we combine the LAUS with national unemployment data at the industry-month level and state-industry-month employment shares from the Quarterly Census of Employment and Wages (QCEW). Our time period spans 2000 through 2015. This period provides rich variation in exposure to labor demand shocks across geography and industries, as these years include two distinct recessions with strikingly different heterogeneity across states and industries (Hershbein and Stuart, 2020).

\subsection{EEO-1 Employment Files}

We further link the EEOC charge data with the EEO-1 files, which provide a rich census of all private establishments in the United States for firms with at least 100 employees, and account for nearly 8 million establishment-year observations. The EEO-1 data cover approximately $40 \%$ of all employees in the country and detail the gender and occupational distribution of workers within an establishment. These data allow us to explore how the gender mix of co-workers and managers influence sexual harassment charges filed by women. We are able to link roughly half of the EEOC sexual harassment charges to this data. ${ }^{15}$

Table 2 compares establishments on the basis of whether they were named as a respondent in a sexual harassment charge in a given year. Offending establishments have 2.8 percentage point more males and 5 percentage point more male managers. In contrast, these establishments have 2.1 percentage points more women in lower-skilled occupations, such as the laborer and service worker categories. Additionally, Southern establishments are disproportionately more likely to be accused of sexual harassment, with the Northeast having the

\footnotetext{
${ }^{15}$ We cannot match all charges for two primary reasons. First, EEOC federal antidiscrimination laws cover all employees at establishments with 15 or more employees, but requires EEO-1 surveys only from those establishments whose firm has 100 or more employees. Second, the EEO-1 files cover only private establishments, whereas approximately $15 \%$ of discrimination charges are leveled against public firms.
} 
fewest charges. This pattern matches the geographic distribution of labor rights violations from 2000-2019 (Marinescu et al., 2020).

\subsection{Unemployment Insurance Data}

To estimate the impact of North Carolina's UI reform, we combine Department of Labor administrative data (ETA Form 5159 data) with monthly Current Population Survey data to calculate short-term UI recipiency rates. Our measure divides the monthly number of individuals receiving weekly UI benefits by the number of short-term unemployed-defined as those unemployed for 26 weeks or fewer-as in Schaefer and Evangelist (2014). This serves as a proxy for the ex-ante probability of receiving short-term unemployment benefits in the event that a worker files a sexual harassment charge and is subsequently dismissed.

In Figure 2, we compare the short-term UI recipiency rate in North Carolina relative to other Southern states that had no changes to their UI programs during the sample period. While the two rates track one another closely prior to July 2013 (the implementation date of North Carolina's reform), they diverge sharply thereafter. Specifically, the fraction of short-term unemployed receiving UI benefits in North Carolina drops precipitously from $33 \%$ to $10 \%$, a $59 \%$ decrease relative to control states, in just over 2 years. We use this large shock to study how the value of outside options influences the willingness to report sexual harassment.

\section{Model}

This section outlines a simple threshold model of sexual harassment reporting behavior. The model predicts that when the cost of becoming unemployed is higher, the harassment threshold above which a worker will report sexual harassment rises. The intuition is that victims will "tough it out" rather than report and potentially jeopardize their current employment at a time when alternate labor market opportunities are limited (Biddle et al., 1998; Boone 
and Van Ours, 2006). The identifying assumption for this result is that a worker's willingness to file a sexual harassment claim depends only on her outside options and the severity of sexual harassment she experiences. Empirically, we also require that the EEOC applies a consistent standard of what constitutes a meritorious case, regardless of the state of the economy.

We begin by introducing a static version of the model in Boone and Van Ours (2006), which looks at the willingness of workers to report occupational injuries. We define $\alpha \geq 0$ as the level of sexual harassment a firm engages in against a particular employee. Given $\alpha$, the worker decides whether to report the sexual harassment. Her harassment claim has probability $p(\alpha)$ of being successful, with $\partial p(\alpha) / \partial \alpha>0$. Should the worker endure the harassment and not report, she receives a payoff of $w$, her wage, minus $\alpha$.

If the worker instead reports, with probability $p(\alpha)$ the hostile work environment is eliminated and she receives compensation $\gamma(\alpha)$, which also depends positively on the level of harassment. However, such a worker also faces the possibility of a retaliatory firing with probability $\theta .{ }^{16}$ In this case she finds a new job with probability $q(u)$ which depends negatively on the current unemployment rate $u$. If she fails to find a job, she receives unemployment benefits. The value of becoming unemployed is the weighted average of the wage at her new job, $w^{\prime}$, and the unemployment benefit, $b$ : $V_{u}=q(u) w^{\prime}+(1-q(u)) b$. The value of remaining employed is the worker's wage at their current job, $w$, minus the amount of sexual harassment they endure (which will be eliminated if their case is successful): $V_{e}=w-(1-p(\alpha)) \alpha$. Thus, a worker will report sexual harassment if:

$$
p(\alpha) \gamma(\alpha)+\theta V_{u}+(1-\theta) V_{e} \geq w-\alpha
$$

where the first term is the monetary gain if the claim is successful, and the next two terms capture the expected payoffs with and without a retaliatory firing. This can be rewritten with the expected gains on one side and the expected losses on the other:

\footnotetext{
${ }^{16}$ For simplicity, the probability of a retaliatory firing is not a function of $\alpha$.
} 


$$
p(\alpha) \gamma(\alpha)+(1-\theta) p(\alpha) \alpha \geq \theta\left[w-\alpha-q(u) w^{\prime}-(1-q(u)) b\right]
$$

The first term on the left hand side is the expected monetary payment and the second is the expected value of eliminating the harassment. We assume $w-\alpha>V_{u}$, i.e., that the worker does not prefer a retaliatory firing to keeping her job.

Since the left hand side is increasing in $\alpha$ while the right hand side is decreasing in $\alpha$, we can define the threshold level of harassment above which an employee will report, $\bar{\alpha}$, as the level of $\alpha$ that satisfies equation 2 with equality:

$$
p(\bar{\alpha}) \gamma(\bar{\alpha})+(1-\theta) p(\bar{\alpha}) \bar{\alpha}=\theta\left[w-\bar{\alpha}-q(u) w^{\prime}-(1-q(u)) b\right]
$$

Equation 3 can be used to analyze the comparative statics of how the reporting threshold $\bar{\alpha}$ responds to a lower value of becoming unemployed. A negative labor demand shock decreases the probability of finding another job, $q(u)$, which leads to a rise in the reporting threshold $\bar{\alpha}$. Similarly, a reduction in the generosity of unemployment benefits, $b$, lowers the value of unemployment and also leads to a rise in the reporting threshold. ${ }^{17}$ The testable implication is that the probability a worker's claim will be successful increases when either $q(u)$ or $b$ decreases.

Note that our theory does not model firm behavior and hence does not make predictions about the volume of reported claims. Our identifying assumption-that a worker's willingness to file a sexual harassment claim depends only on her outside options and the severity of sexual harassment she experiences-does not require us to model firm behavior. The expected benefits and costs to a firm of sexually harassing workers could depend on the business cycle. Moreover, an employer could take advantage of higher reporting thresholds by increasing the amount (i.e., number of employees harassed) and the severity of sexual harassment in the workplace. Whether this will show up in equilibrium as an increase or decrease in the volume of reported claims is ambiguous.

\footnotetext{
${ }^{17}$ More formally, we can define a reporting function, $R(\bar{\alpha}, u, b)$, that equals equation 3 . Using the implicit function theorem to take derivatives, it is easy to verify the statements in the text.
} 


\section{$5 \quad$ Empirical Framework}

\subsection{Labor Demand Shocks and the Selectivity of Charges}

We first estimate the effect of local labor market slackness on the selectivity/quality of sexual harassment charges filed with the EEOC much in the spirit of Maestas et al. (2021), who study the relationship between labor market conditions and disability insurance claims at the state-month level. Like Dahl and Knepper (2020), we exploit rich monthly heterogeneity in exposure to downturns across both geography and industries. We combine data on state-month unemployment from the LAUS with national industry-month unemployment and state-industry-month employment from the QCEW to impute $U_{j s t}$, the number of unemployed individuals in a state-industry-month. ${ }^{18}$

As our primary hypothesis concerns how the selectivity of sexual harassment reports responds to the health of the relevant labor market, we first regress whether a charge received merit on $U_{j s t}$ while controlling for other relevant case characteristics as follows:

$$
\text { merit }_{i j s t}=\beta U_{j s t}+\gamma_{j}+\alpha_{s}+\theta_{t}+\pi X_{i}+\epsilon_{i j s t}
$$

where $i$ is the individual, $j$ the industry, $s$ the state, and $t$ the month. The merit $t_{i j s t}$ variable is an indicator for whether the individual charge in a particular state-industrymonth cell receives a merit designation by the EEOC. $X_{i}$ measures the race, age, and sex of the charging party, though our results are invariant to the inclusion of these covariates. In all specifications, we cluster our standard errors at the state-level to allow for arbitrary correlation in merit decisions reached by each of the 53 local EEOC offices over the course of the sample period.

Following Maestas et al. (2021) and Dahl and Knepper (2020), our main independent variable of interest is the number unemployed, rather than the unemployment rate. We do this to sidestep any potential confounding effects introduced by industry-state-time differ-

\footnotetext{
${ }^{18}$ See Dahl and Knepper (2020) for further details on the imputation procedure.
} 
ences in the size of the labor force. Reassuringly, our results are robust to using levels instead of unemployment rates. We control further for $\gamma_{j}, \alpha_{s}$, and $\theta_{t}$, which capture fixed effects for industry, state, and time. In doing so, we absorb heterogeneity in charge selectivity that is unrelated to negative labor demand shocks at either the industry or state level, or part of a broader national trend. Our identifying assumption is that a worker's willingness to file a sexual harassment claim depends only on her outside options and the severity of sexual harassment she experiences after conditioning out the fixed effects.

\subsection{North Carolina Reform and the Selectivity of Charges}

We also estimate how the reductions in North Carolina's UI program affected the quality of sexual harassment charges filed. The reduced form regression is:

$$
\text { merit }_{i s t}=\phi\left(\text { North } \text { Carolina }_{i s} \times \text { post }_{s t}\right)+\alpha_{s}+\theta_{t}+\epsilon_{i s t}
$$

The coefficient of interest is $\phi$, the effect of the North Carolina UI reform on the quality of sexual harassment charges. As before, $\alpha_{s}$ and $\theta_{t}$ are state and month-year fixed effects. Because this is a difference-in-differences design, identification requires that the quality of sexual harassment charges filed in North Carolina in the absence of the reform would have evolved identically as in the control states (other Southern states). We also present a yearly event study and document parallel pre-trends. Our control group of other Southern states excludes four Southern states which changed their UI programs (AR, FL, GA, SC). It includes those from the South Atlantic (DE, DC, MD, VA, WV) and East South Central Census Divisions (AL, KY, MS, TN), but excludes those from the West South Central (LA, OK, TX) as this division exhibits differential pre-trends in merit (see Appendix Figure A1).

We estimate an instrumental variable (IV) regression to scale the magnitude of the reduced form effect. To do this, we run a first stage regression of the short-term UI recipiency rate in a state and year on the North Carolina post-reform dummy. The UI recipiency rate captures the likelihood an individual receives short-term support in the event she is fired. 
The parameter of interest is the elasticity of the quality of sexual harassment charges to the probability of receiving short-term UI following the NC reform. Our theoretical model predicts that this elasticity will be negative.

\section{Results Using Unemployment Shocks}

This section reports our empirical findings for unemployment shocks. We first assess whether workers report sexual harassment more selectively during recessions. We then extend this analysis by documenting facts related to the gendered nature of workplace sexual harassment and providing insights into possible mechanisms.

\subsection{Labor Demand Shocks and the Selectivity of Charges}

Figure 3 depicts graphically the relationship between the unemployment rate in an industrystate-month cell and the fraction of sexual harassment charges deemed to have had merit by the EEOC after residualizing out state, industry, and time fixed effects. There exists a clear, positive relationship between the two variables, indicating that victims of sexual harassment are relatively more selective about filing charges in weak labor markets. This accords with the theoretical prediction that a reduction in outside labor market opportunities causes workers to raise the threshold level of sexual harassment they will tolerate before filing a report.

Column (1) of Table 3 reports regression estimates for the effect of a 1 person increase in the number unemployed in a state-month-industry on the fraction of sexual harassment charges with merit, controlling for industry, state, and time fixed-effects (and the victim's race, sex, and age). To calculate the effect of a 1 percentage point increase in the local unemployment rate on merit, we multiply $\beta$ by $1 \%$ of the size of a labor force in a stateindustry-month cell, which is approximately 623,000. We find that each one percentage point increase in the local unemployment rate increases the fraction of charges with merit by 0.0012 percentage points. This amounts to approximately a 0.5 percent increase relative 
to the mean. During the Great Recession unemployment rose from $4.5 \%$ to a $10 \%$, so that from the trough to the peak, our estimates imply that merit increased by $2.5 \%$.

We next restrict attention to charges involving employer retaliation in column (2). The rationale is that we can be certain that these charges were filed while the individual was still employed. Non-retaliatory sexual harassment charges, on the other hand, include some that were filed following a discharge. Because there is no threat of job loss, discharged employees may in fact face a lower threshold for filing a discrimination or harassment complaint. The estimate using this alternative subsample is slightly larger.

Columns (3)-(4) of Table 3 re-estimate the above relationships, relying only on statemonth variation in the unemployment rate. To determine the effect of a 1 percentage point increase, we multiply the coefficient of interest by $1 \%$ of the average size of a state's labor force, which is 5.7 million. Both specifications imply that a 1 percentage point increase in local unemployment increases the quality of sexual harassment charges by roughly $1 \%$.

As a robustness exercise, in Appendix Table A1, we re-estimate the baseline relationship but instead use the imputed unemployment rate and employment-to-population ratios as the relevant measures of labor market tightness. Column (1) reveals that each one percentage point increase in the local unemployment rate increases the fraction of charges with merit by 0.0029 off a baseline of $27 \%$, which translates to a $1.1 \%$ increase. Similar effects are found for retaliatory charges in column (2). Likewise, each one percentage point decrease in the employment-to-population ratio generates a 2.1 (1.4) percentage point increase in the quality of all (retaliatory) sexual harassment charges filed.

Recall that a charge may be categorized as meritorious by the EEOC either if the firm and claimant reach a settlement voluntarily or if the EEOC's investigation determines that the case has reasonable cause after a lengthy investigation. As another robustness exercise, we run a multinomial logit which has three outcomes: no merit, merit due to settlement, and merit due to reasonable cause. The implied effects of a $1 \%$ increase in unemployment, evaluated at the means of the number unemployed in an industry-state-month, are reported 
in Appendix Table A2. We find unemployment effect sizes which are similar for both merit due to settlement (a $0.53 \%$ increase) or reasonable cause (a $0.38 \%$ increase). The two are jointly significant, but due to collinearity, only one of the two is individually statistically significant. When restricted to retaliatory charges, the effect on merit due to reasonable cause grows to $0.91 \%$ and both estimates become individually statistically significant.

If individuals are more liquidity constrained during recessions, they could have substituted towards settlement more often in order to avoid a roughly 10-month EEOC investigation to determine cause. However, as the multinomial logit estimates show, this does not appear to be the case, as both settlements and reasonable cause rulings increase.

\subsection{Labor Demand Shocks and the Volume of Charges}

As a reminder, our model does not make a prediction about the volume of reported claims, as this would require assumptions about firm behavior. With this caveat in mind, Table A3 shows the effects of unemployment on the volume of sexual harassment charges being filed. ${ }^{19,20}$ These capture any potential responses by the firm to the increase in victims' reporting thresholds. Absent any employer response, an increase in selectivity would imply a reduction in the volume of sexual harassment charges filed. However, we find that a 1 percentage point increase in local unemployment rates increases the volume of charges filed by $0.6-1.3$ percentage points, although the estimates are somewhat imprecise. This positive effect suggests that in spite of victims increasing the selectivity of their reports, employers sexually harass their employees in a way that exceeds this threshold at an even higher rate in weak labor markets. In other words, firms are willing to get caught at a higher frequency when the reporting threshold increases.

\footnotetext{
${ }^{19}$ Because these data are collapsed to the state-month-industry level-unlike the individual-level merit regressions-we weight by the size of the relevant labor force.

${ }^{20}$ Cassino and Besen-Cassino (2019) and Juban and Wallace (2005) analyze how the volume of charges responds to unemployment at the national level, reaching opposite conclusions from one another.
} 


\subsection{The Impact of Gender in the Workplace Using Linked Data}

We now document several facts about workplace sexual harassment and explore potential mechanisms. To do this, we link in data on the gender distribution of workers at the establishment level. We find evidence that the gender make-up of a workplace plays a prominent role in determining the selectivity and amount of sexual harassment charges. Since $84 \%$ of all victims in our data are female, this subsection focuses on women.

Figure 4a shows that the selectivity of charges is monotonically increasing in the fraction of male workers at an establishment, while at the same time panel 4c documents that the number of charges per woman rises. This suggests that in male-dominated environments, female employees become increasingly reluctant to report despite an increase in volume. The volume result accords with Folke and Rickne (2020); a measure of selectivity is not contained in their dataset, so no comparison is possible on that margin.

In Figure 4b, we explore whether gendered power dynamics (Hesson-Mcinnis and Fitzgerald, 1997; MacKinnon, 1979) play a role. We find the selectivity of charges filed by females is increasing in the fraction of managers who are male. Panel $4 \mathrm{~d}$ shows that charge volume increases monotonically in the fraction of male managers. Combined, these patterns suggest that a lack of women in power contributes both to a more sexually hostile work environment and to an increased fear of reporting illegal behavior due to a fear of retaliation. The volume result is interesting, as it diverges from the survey-based evidence in Folke and Rickne (2020). One possible explanation is that their measure captures whether an individual's closest supervisor is of the opposite sex whereas ours summarizes the extent to which a power hierarchy runs across gender lines more broadly within a workplace.

Table 4 displays heterogeneity in the selectivity of harassment charges filed by employees during recessions by (i) the percent of men in an industry and (ii) the extent to which males dominate managerial roles within a workplace. The table uses the same specification as Table

3. A one standard deviation increase in either of these margins amplifies the underreporting effect due to one percentage point higher unemployment by approximately $0.3 \%$. Taken 
together, these results suggest that the threat of retaliation from male colleagues and male managers becomes an increasingly effective deterrent to reporting as outside labor market opportunities become scarcer.

\section{North Carolina's UI Reform and Underreporting}

In this section we report empirical findings for North Carolina's UI reform. We show results in event-study figures and estimate difference-in-difference regressions, as well as IV estimates which scale the underreporting effect of the reform by the change in the UI recipiency rate.

In July 2013, the maximum level of regular state-level UI benefits available to North Carolinians fell by $50 \%$, from $\$ 14,000$ to $\$ 7,000$. These curtailments sharply reduced the short-term UI recipiency rate relative to other Southern states which did not change their UI programs (see Section 2.2 and Figure 2). If outside options are pivotal in victims' decisions to report workplace sexual harassment, it follows that the UI reform could exacerbate underreporting by magnifying the loss of income after a retaliatory discharge (which occurs in $63 \%$ of charges). Wrongful terminations, such as retaliatory firings, are illegal and so the worker should in theory qualify for unemployment benefits. If the worker is simply let go, and not fired for cause, she will be eligible for benefits. If instead she is fired for cause, she must prove to the UI office that she was the victim of a wrongful termination.

In Figure 5a we plot the fraction of cases with merit in each year before and after the reform, for North Carolina versus other Southern states. We normalize the merit rate for the two groups to be the same in the year leading up to the reform. ${ }^{21}$ Prior to the reform, merit in both treatment and control states is trending down, consistent with selectivity falling as the economy recovered from the Great Recession. There is no evidence for differential pretrends. However, in the 12 months after the reform, the fraction of cases with merit spikes in North Carolina but not in other Southern states.

\footnotetext{
${ }^{21}$ In the year leading up to the reform, North Carolina's merit rate was $17 \%$, while it was $24 \%$ in other Southern states.
} 
In Figure 5c we plot regression-adjusted (netting out state and year fixed effects) eventstudy coefficients for the difference between treatment and control. There is a 7 percentage point rise in North Carolina relative to other Southern states in the year after the reform. This elevated rate persists in years two and three post reform, consistent with the fact that North Carolina's reduction in UI benefits was permanent.

Instrumental variable regression estimates can be found in columns (1) and (2) of Table 5. The first stage regresses the short-term UI recipiency rate in a state and year on a North Carolina post-reform dummy. Panel A of Table 5 reveals that after the reform, there was a 20 percentage point drop in UI recipiency, relative to a pre-reform mean of $46 \%$. Turning to Panel B, column (1) shows that, following North Carolina's reform, the selectivity of sexual harassment charges increases by $33 \%$, or 7 percentage points off a baseline $21 \%$ merit rate. To scale the magnitude of the reduced form effect, we estimate an IV regression in column (2). The IV estimate indicates that each one percentage point increase in the UI recipiency rate causes a 0.35 percentage point decrease in selectivity. Since a higher UI recipiency rate mediates the effects of a retaliatory firing, this large response is consistent with increased underreporting in the absence of a generous social safety net.

As an alternative approach, we estimate treatment effects using various types of synthetic control groups. To start, we construct synthetic weights by matching on the state female unemployment rate. Matching uses both the pre-reform state female unemployment rate as well as a variety of other pre-reform labor market characteristics as predictor variables. The extra predictors include the overall state unemployment rate, state female employment to population ratio, the state female labor force participation rate, and state-industry employment weights. Note that this approach does not match on the outcome variable of merit, or use merit to predict state female unemployment rates. These weights are found in column (1) of Appendix Table A4. Alabama contributes almost half the weight, with Oregon, Connecticut, Nevada, and New Jersey being the other top donor states. There are 35 possible donor states as we exclude states that had changes to their UI program and small states 
that had 0 sexual harassment charges in at least 1 year.

Figure 5b plots the fraction of cases with merit for North Carolina as compared to our synthetic control sample, similar to Figure 5a. The synthetic controls, which were not constructed by matching on the outcome variable, nevertheless closely track North Carolina in the pre-period. In contrast, merit in North Carolina increases sharply following the reform, while there is no detectable deviation from trend for the synthetic controls. Figure 5 d plots the event-study coefficients, and reveals a more than 8 percentage point rise in merit in North Carolina in all years following the reform. Columns (3) and (4) of Table 5 report corresponding IV regression estimates. The estimates are similar to those which use other Southern states as controls.

Figure A2 plots the merit rate in North Carolina against each of the 7 donor states to provide a visualization of the trends in each individual state used to construct the synthetic control. Figure A3 performs a standard placebo test which plots the difference between the merit rate in each state and that of its own synthetic control group. While the pre-reform placebo differences in merit are somewhat noisy, North Carolina exhibits among the largest growth in merit compared to its synthetic control group in the post-reform period.

To probe the robustness of our synthetic control estimates, we add merit as an additional predictor variable, but keep the matching variable as the state female unemployment rate. This alters the set of donor states, with weights primarily on Nevada, Kentucky, California, and Arizona (see Appendix Table A4). As another alternative, we match on the outcome variable of merit using only state unemployment and merit as predictor variables. The largest donor states are now Nevada and Iowa. Event study graphs for both of these specifications are found in Appendix Figure A4. Using either approach, the general pattern replicates.

From the analyses of North Carolina's UI reform, we conclude that willingness to report sexual harassment depends crucially on outside options. 


\section{Conclusion}

This paper provides a novel exploration of the underreporting of workplace sexual harassment. We measure the quality of charges using the universe of charges filed with the EEOC to study how economic conditions, workplace characteristics, and UI generosity each influence the incentive for victims to report sexual harassment in the workplace. The nature of the data allows us to focus on a margin that has been largely overlooked in the literature: worker reporting incentives. This element is often missed when analyzing anonymous surveys of workplace sexual harassment, as victims are shielded from any economic consequences associated with outing their employers. We view the two types of data as useful complements for a better understanding of workplace sexual harassment, and how best to combat it.

We find that reductions in outside job opportunities and in the generosity of unemployment insurance each make employees more vulnerable to sexually hostile work environments. We also document rich heterogeneity along several dimensions using linked employeeemployer data that connects sexual harassment charges to the gender make-up of the workplace.

One way to think about the underreporting problem is that it stems from an inefficient allocation of costs across firms and employees. If employees face reporting costs that are amplified by the prospect of retaliatory firings, they will underreport. A direct way to both curb firm misconduct and encourage reporting would be to raise the costs borne by employers in the event that they are found culpable, particularly when a charge involves retaliation. These penalties could even be made countercyclical, to more aggressively deter illegal harassment when the costs of speaking out are highest. Moreover, the expansion of social safety net programs, such as UI, may efficiently increase ex-ante moral hazard by

shrinking the penalty of a retaliatory firing and hence, implicitly encouraging victims to report sexual harassment they might otherwise not. 


\section{References}

Acken, Brenda T, Kent St Pierre, and Peter Veglahn, "Limiting Sexual Harassment Liability," Journal of Accountancy, 1991, 171 (6), 42.

Baker, Michael and Samuel A Rea Jr, "Employment Spells and Unemployment Insurance Eligibility Requirements," Review of Economics and Statistics, 1998, 80 (1), 80-94.

Berrey, Ellen, Robert L Nelson, and Laura Beth Nielsen, Rights on Trial: How Workplace Discrimination Law Perpetuates Inequality, University of Chicago Press, 2017.

Biddle, Jeff, Karen Roberts, Kenneth D Rosenman, and Edward M Welch, "What Percentage of Workers with Work-related Illnesses Receive Workers' Compensation Benefits?," Journal of Occupational and Environmental Medicine, 1998, 40 (4), 325-331.

Boone, Jan and Jan C Van Ours, "Are Recessions Good for Workplace Safety?," Journal of Health Economics, 2006, 25 (6), 1069-1093.

_ , _ , Jean-Philippe Wuellrich, and Josef Zweimüller, "Recessions are Bad for Workplace Safety," Journal of Health Economics, 2011, 30 (4), 764-773.

Borker, Girija, "Safety First: Perceived Risk of Street Harassment and Educational Choices of Women," Department of Economics, Brown University, 2017, pp. 12-45.

Card, David and Phillip B Levine, "Extended Benefits and the Duration of UI Spells: Evidence from the New Jersey Extended Benefit Program," Journal of Public Economics, 2000, 78 (1-2), 107-138.

Cassino, Dan and Yasemin Besen-Cassino, "Race, Threat and Workplace Sexual Harassment: The Dynamics of Harassment in the United States, 1997-2016," Gender, Work \& Organization, 2019, 26 (9), 1221-1240.

Cheng, Ing-Haw and Alice Hsiaw, "Reporting Sexual Misconduct in the\# MeToo Era," Available at SSRN 3506936, 2020.

Christofides, Louis $\mathbf{N}$ and Chris J McKenna, "Unemployment Insurance and Job Duration in Canada," Journal of Labor Economics, 1996, 14 (2), 286-312.

Cortina, Lilia M and Vicki J Magley, "Raising Voice, Risking Retaliation: Events following Interpersonal Mistreatment in the Workplace," Journal of Occupational Health Psychology, 2003, 8 (4), 247.

Crull, Peggy, "Stress Effects of Sexual Harassment on the Job: Implications for Counseling," American Journal of Orthopsychiatry, 1982, 52 (3), 539.

Dahl, Gordon B and Matthew Knepper, "Age Discrimination across the Business Cycle," NBER Working Paper, 2020, 27581.

Faley, RH, DE Knapp, GA Kustis, and CLZ DuBois, "Organizational Costs of Sexual Harassment in the Workplace: The Case of the US Army," in "Ninth Annual Conference of the Society of Industrial and Organizational Psychology, Nashville, TN" 1994.

Farber, Henry S and Robert G Valletta, "Do Extended Unemployment Benefits Lengthen Unemployment Spells? Evidence from Recent Cycles in the US Labor Market," Journal of Human Resources, 2015, 50 (4), 873-909.

_ , Jesse Rothstein, and Robert G Valletta, "The Effect of Extended Unemployment Insurance Benefits: Evidence from the 2012-2013 Phase-out," American Economic Review Papers 85 Proceedings, 2015, 105 (5), 171-76.

Feldblum, Chai R and Victoria A Lipnic, "Select Task Force on the Study of Harass- 
ment in the Workplace," Washington: US Equal Employment Opportunity Commission, 2016.

Fitzgerald, Louise F, Charles L Hulin, and Fritz Drasgow, "The Antecedents and Consequences of Sexual Harassment in Organizations: An Integrated Model," 1994.

_, Sandra L Shullman, Nancy Bailey, Margaret Richards, Janice Swecker, Yael Gold, Mimi Ormerod, and Lauren Weitzman, "The Incidence and Dimensions of Sexual Harassment in Academia and the Workplace," Journal of Vocational Behavior, 1988, 32 (2), 152-175.

_, Vicki J Magley, Fritz Drasgow, and Craig R Waldo, "Measuring Sexual Harassment in the Military: the Sexual Experiences Questionnaire (SEQ-DoD)," Military Psychology, 1999, 11 (3), 243-263.

Folke, Olle and Johanna Karin Rickne, "Sexual Harassment and Gender Inequality in the Labor Market," 2020.

Frierson, James G, "Sexual Harassment in the Workplace Costly in Production, Absenteeism, Turnover," Preventive L. Rep., 1989, 8, 3.

GAO, "Unemployment Insurance: States' Reductions in Maximum Benefit Durations have Implications for Federal Costs," Technical Report, Report 15-281 2015.

Grittner, Amanda and Matthew S Johnson, "When Labor Enforcement and Immigration Enforcement Collide: Deterring Worker Complaints Worsens Workplace Safety," Available at SSRN 3756974, 2020.

Gutek, Barbara A, Sex and the Workplace, Jossey-Bass San Francisco, 1985.

_ and Mary P Koss, "Changed Women and Changed Organizations: Consequences of and Coping with Sexual Harassment," Journal of Vocational Behavior, 1993, 42 (1), 28-48.

Hersch, Joni, "Compensating Differentials for Sexual Harassment," American Economic Review Papers 65 Proceedings, 2011, 101 (3), 630-34.

_ , "Valuing the risk of workplace sexual harassment," Journal of Risk and Uncertainty, 2018, 57 (2), 111-131.

Hershbein, Brad and Bryan A Stuart, "Recessions and Local Labor Market Hysteresis," 2020.

Hesson-Mcinnis, Matthew S and Louise F Fitzgerald, "Sexual Harassment: A Preliminary Test of an Integrative Model 1," Journal of Applied Social Psychology, 1997, 27 (10), 877-901.

Johnson, Matthew S, Daniel Schwab, and Patrick Koval, "Legal Protection Against Retaliatory Firing Improves Workplace Safety," Available at SSRN 3619384, 2020.

Johnston, Andrew C and Alexandre Mas, "Potential Unemployment Insurance Duration and Labor Supply: The Individual and Market-level Response to a Benefit Cut," Journal of Political Economy, 2018, 126 (6), 2480-2522.

Juban, Rusty and Dawn Wallace, "Sexual Harassment and the Unemployment Rate: Explaining the Under-reporting of Sexual Harassment Claims," in "Allied Academies International Conference. Academy of Organizational Culture, Communications and Conflict. Proceedings," Vol. 10 Jordan Whitney Enterprises, Inc 2005, p. 29.

Katz, Lawrence F and Bruce D Meyer, "The Impact of the Potential Duration of Unemployment Benefits on the Duration of Unemployment," Journal of Public Economics, 
1990, 41 (1), 45-72.

Knapp, Deborah Erdos, Robert H Faley, Steven E Ekeberg, and Cathy LZ Dubois, "Determinants of Target Responses to Sexual Harassment: A Conceptual Framework," Academy of Management Review, 1997, 22 (3), 687-729.

Laband, David N and Bernard F Lentz, "The Effects of Sexual Harassment on Job Satisfaction, Earnings, and Turnover among Female Lawyers," ILR Review, 1998, 51 (4), 594-607.

Lazear, Edward P, Kathryn L Shaw, and Christopher Stanton, "Making Do with Less: Working Harder during Recessions," Journal of Labor Economics, 2016, 34 (S1), S333-S360.

Levy, Roee and Martin Mattsson, "The Effects of Social Movements: Evidence from\# MeToo," Available at SSRN, 2019.

Light, Audrey and Yoshiaki Omori, "Unemployment Insurance and Job Quits," Journal of Labor Economics, 2004, 22 (1), 159-188.

Lusher, Lester, Geoffrey Schnorr, and Rebecca Taylor, "Unemployment Insurance as a Worker Indiscipline Device? Evidence from Scanner Data," SSRN, 2020.

MacKinnon, Catharine A, Sexual Harassment of Working Women: A Case of Sex Discrimination number 19, Yale University Press, 1979.

Maestas, Nicole, Kathleen J Mullen, and Alexander Strand, "The Effect of Economic Conditions on the Disability Insurance Program: Evidence from the Great Recession," Journal of Public Economics, 2021, 199, 104410.

_ , _ , David Powell, Till Von Wachter, and Jeffrey B Wenger, "Working Conditions in the United States: Results of the 2015 American Working Conditions Survey," RAND Corporation, 2017.

Marinescu, Ioana, "The General Equilibrium Impacts of Unemployment Insurance: Evidence from a Large Online Job Board," Journal of Public Economics, 2017, 150, 14-29.

- and Daphné Skandalis, "Unemployment insurance and job search behavior," The Quarterly Journal of Economics, 2021, 136 (2), 887-931.

_, Yue Qiu, and Aaron Sojourner, "Wage Inequality and Labor Rights Violations," SSRN, 2020.

McCann, Carly, Donald Tomaskovic-Devey, and Lee Badgett, "Employers' Responses to Sexual Harassment," Available at SSRN 3407960, 2018.

McHugh, Rick and Will Kimball, "How Low Can We Go? State Unemployment Insurance Programs Exclude Record Numbers of Jobless Workers," Economic Policy Institute, March, 2015, 9.

Merit, US, "US Merit Systems Protection Board," Whistle-Blowing and the Federal Employee, US Government Printing Office, Washington, DC, 1981.

Moffitt, Robert, "Unemployment Insurance and the Distribution of Unemployment Spells," Journal of Econometrics, 1985, 28 (1), 85-101.

Rothstein, Jesse, "Unemployment Insurance and Job Search in the Great Recession," Technical Report, National Bureau of Economic Research 2011.

Schaefer, Luke and Michael Evangelist, "The Impact of the 2011 Changes to Michigan's Unemployment Insurance Program on Unemployed Workers and their Families," Technical 
Report, Michigan Unemployment Insurance Project 2014.

Schmieder, Johannes F and Till Von Wachter, "The Effects of Unemployment Insurance Benefits: New Evidence and Interpretation," Annual Review of Economics, 2016, 8, $547-581$.

Sockin, Jason, Aaron Sojourner, and Evan Starr, "Non-Disclosure Agreements and Externalities from Silence," Available at SSRN, 2021.

Stainback, Kevin and Donald Tomaskovic-Devey, Documenting Desegregation: Racial and Gender Segregation in Private Sector Employment since the Civil Rights Act, Russell Sage Foundation, 2012.

Till, Frank J, Sexual Harassment: A Report on the Sexual Harassment of Students, US Department of Education, 1980. 


\section{$9 \quad$ Figures}

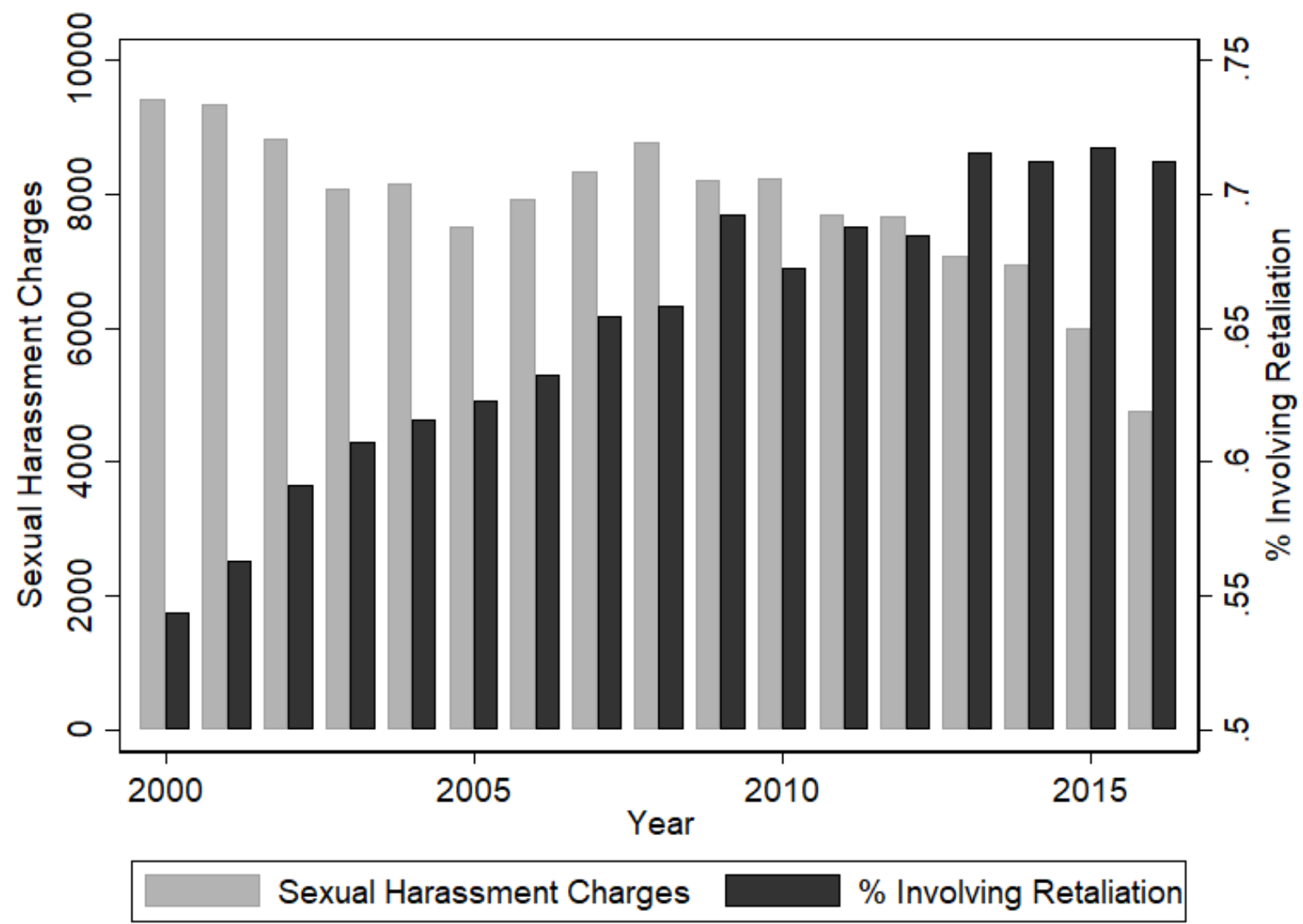

Figure 1: Sexual Harassment Charge Volume and \% Involving Employer Retaliation

Annual number of nationally aggregated sexual harassment charges filed with the EEOC and the fraction of those charges for which the employer retaliated against the claimant. Charge data are missing in last 3 months of 2010 and first 9 months of 2011, and so charges in these years are scaled by 0.75 and 0.25 , respectively. 


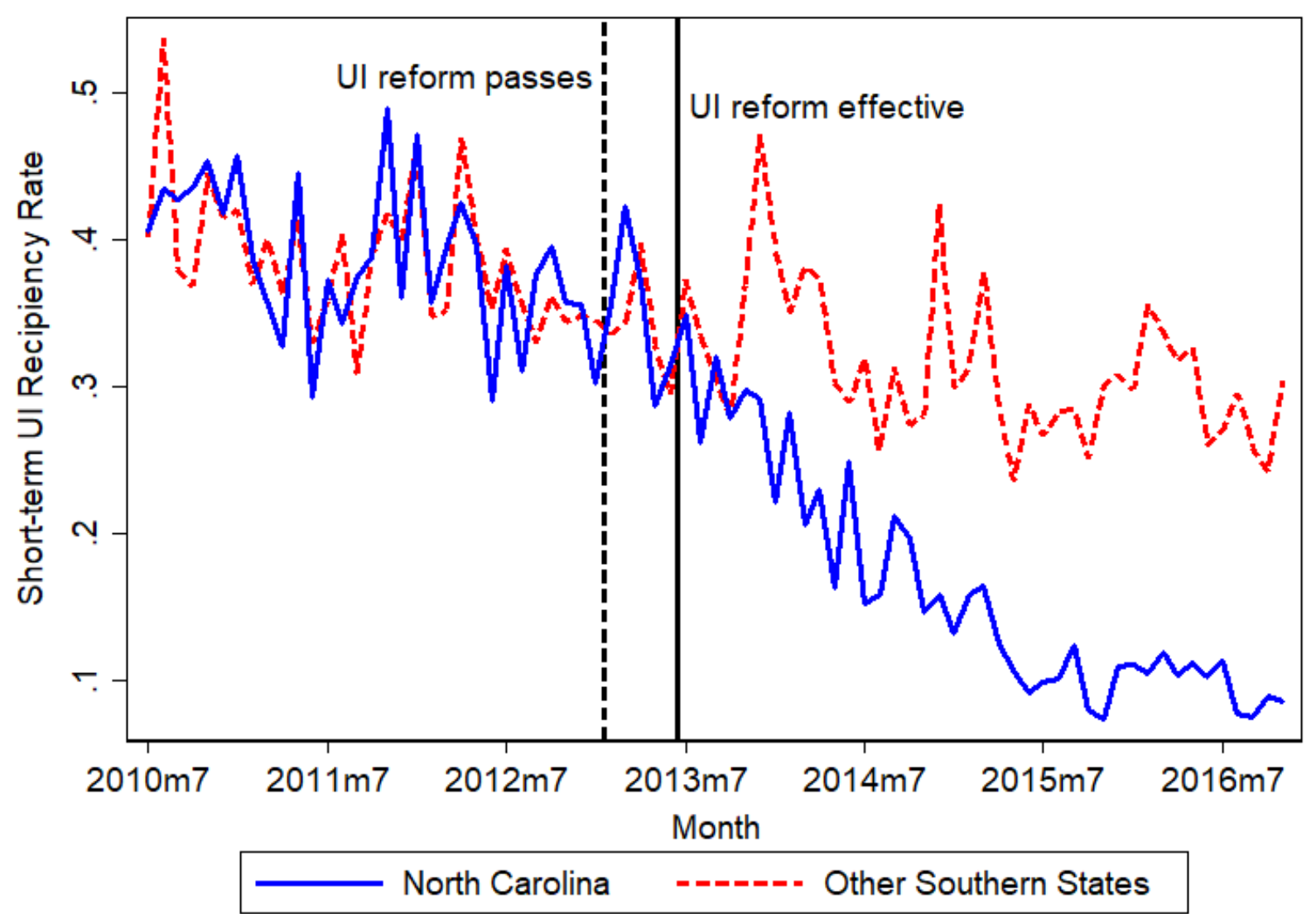

Figure 2: UI Recipiency Rate for North Carolina versus Other Southern States

Short-term UI recipiency rate is the monthly average of total weeks compensated under regular state UI programs divided by the monthly number of short-term unemployed workers. Other Southern States include all states without UI changes from the South Atlantic and East South Central Census Divisions: Delaware, District of Columbia, Maryland, Virginia, West Virginia, Alabama, Kentucky, Mississippi, and Tennessee. 


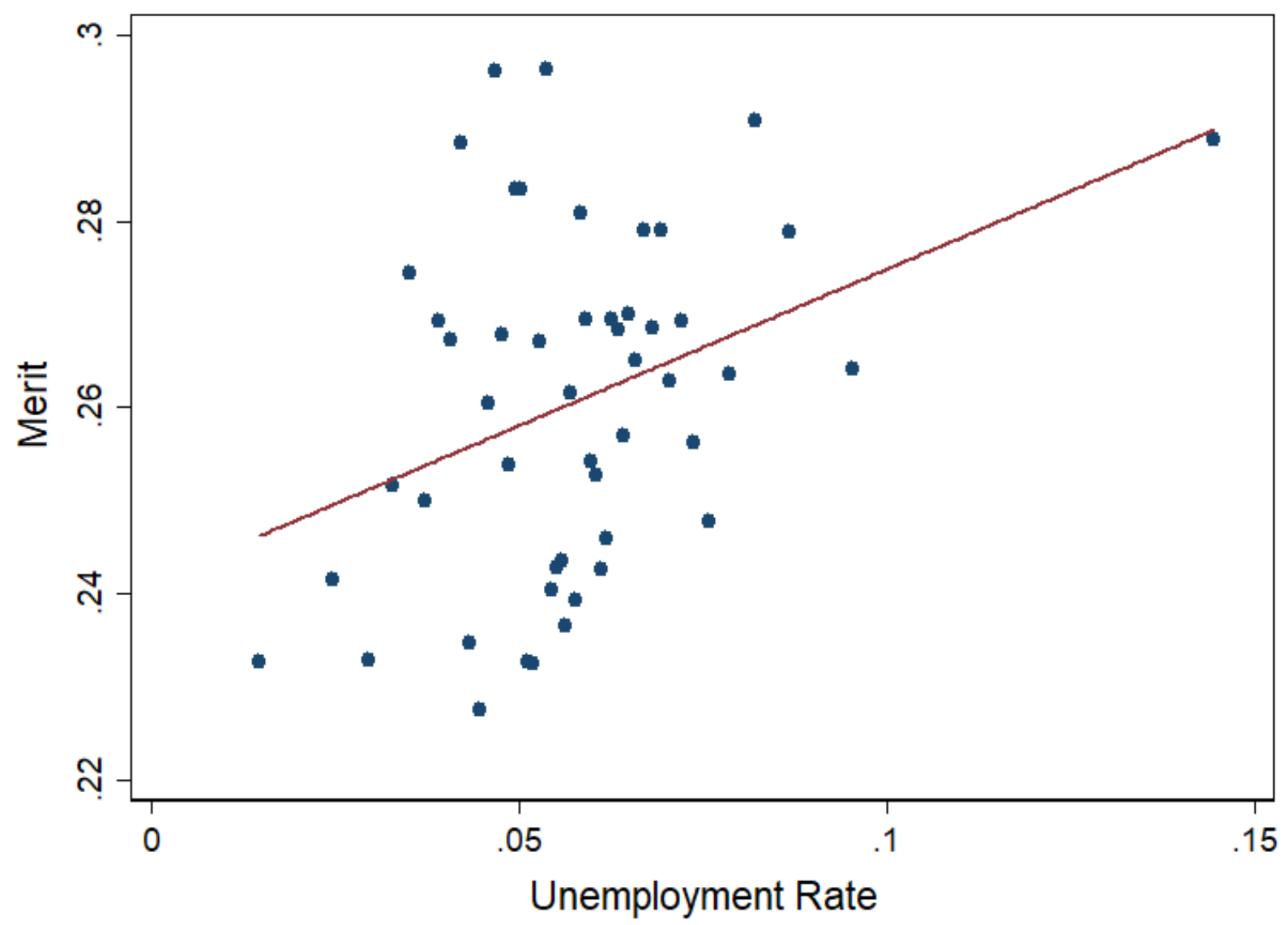

Figure 3: Unemployment Rate and the Fraction of Sexual Harassment Charges with Merit

The $\mathrm{y}$-axis measures the fraction of charges determined to have merit by the EEOC in a state-industry-month unemployment rate bin. Both variables residualize out state, industry, and time fixed effects. Observations are weighted by the industry share of employment in each state's labor force, and cover the period from $2000-2015$. 


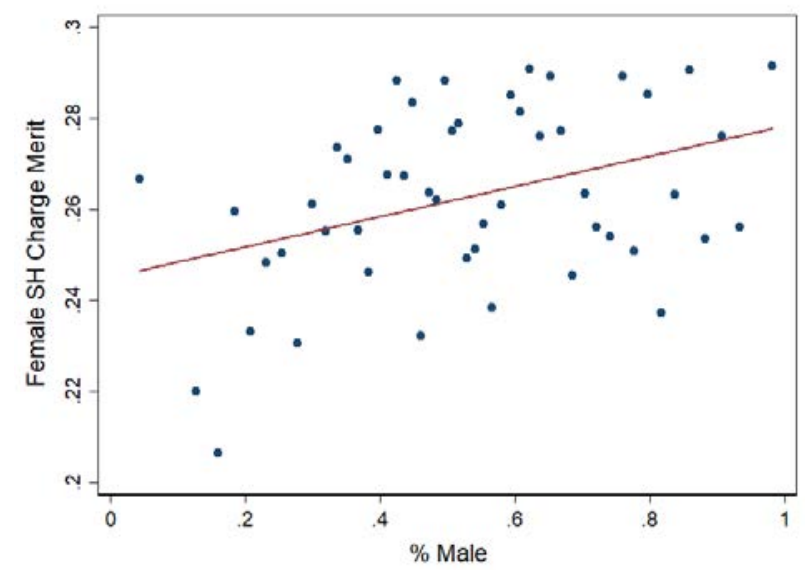

(a)

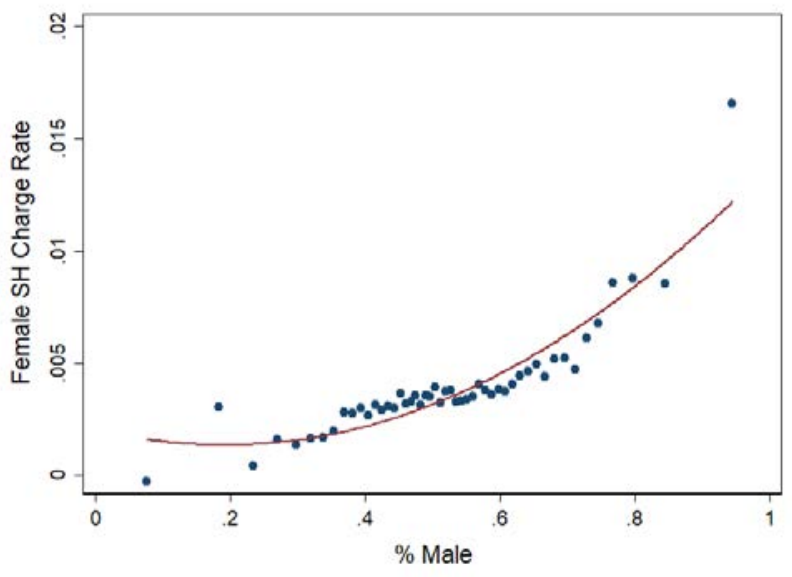

(c)

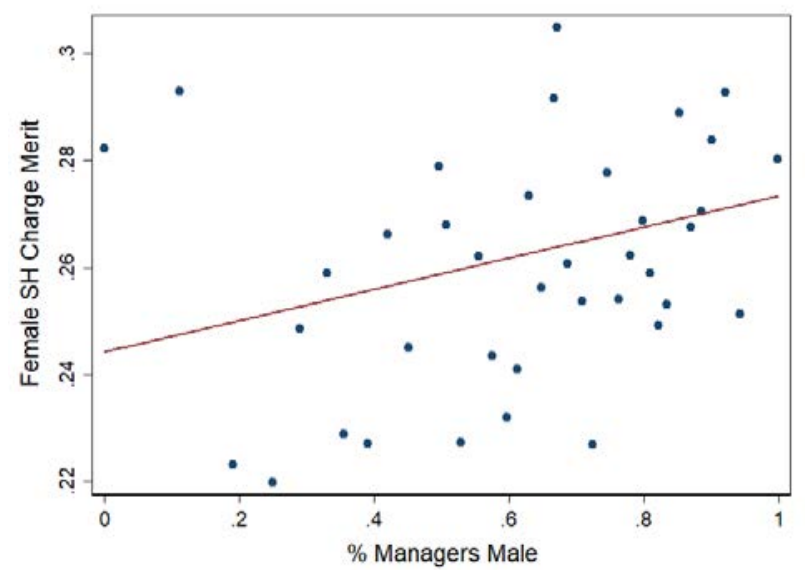

(b)

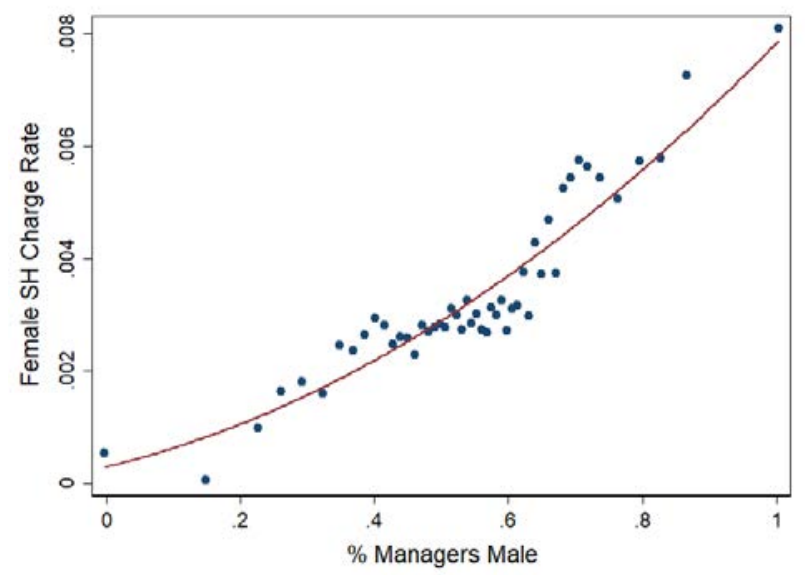

(d)

Figure 4: SH Merit and Charges by \% Male and \% Managers Male within Establishments

Female SH Charge Merit and Rate, respectively, measure the fraction of sexual harassment charges filed by women determined to have merit by the EEOC, and the number of charges filed by women divided by the number of women in an establishment. \% Male and \% Managers Male, respectively, are the fraction of males and fraction of managers who are male in an establishment. All variables residualize out month-year, state, and industry fixed effects, as well as the size of the establishment and the number of establishments within the enveloping firm. Linear and quadratic regression lines appear in the top and bottom panels, respectively. Sample period covers 2000-2015. 


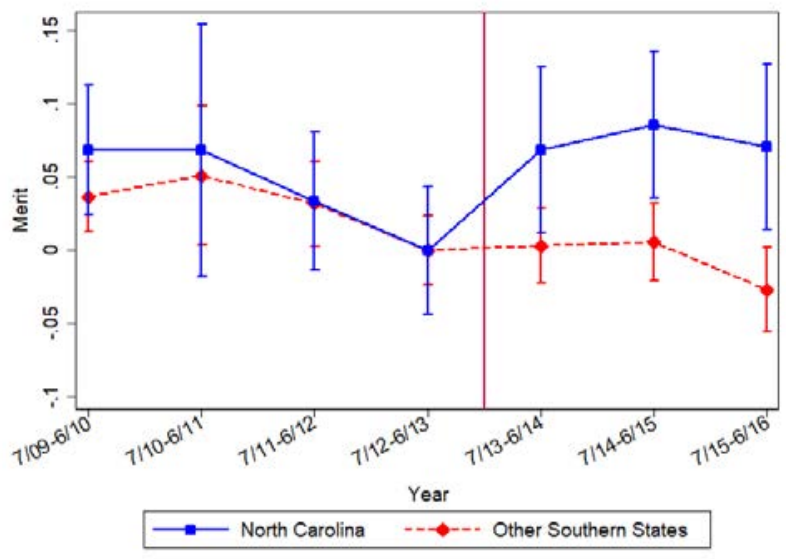

(a)

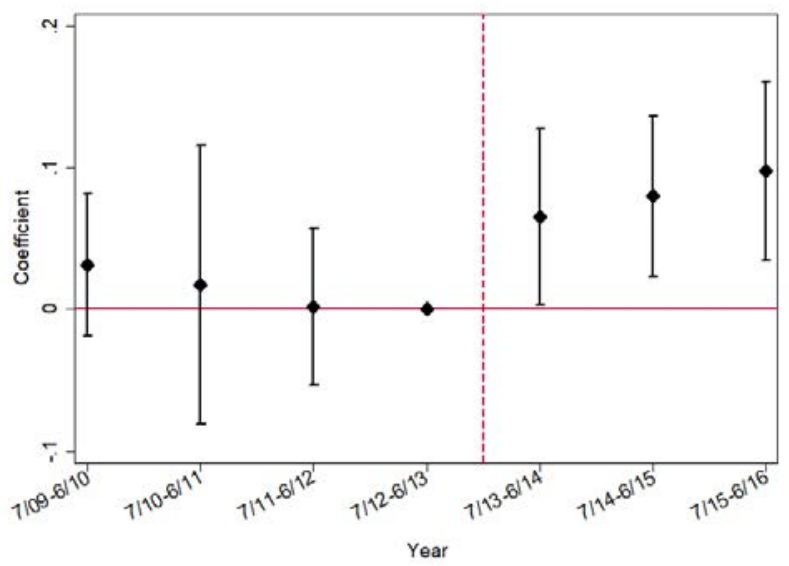

(c)

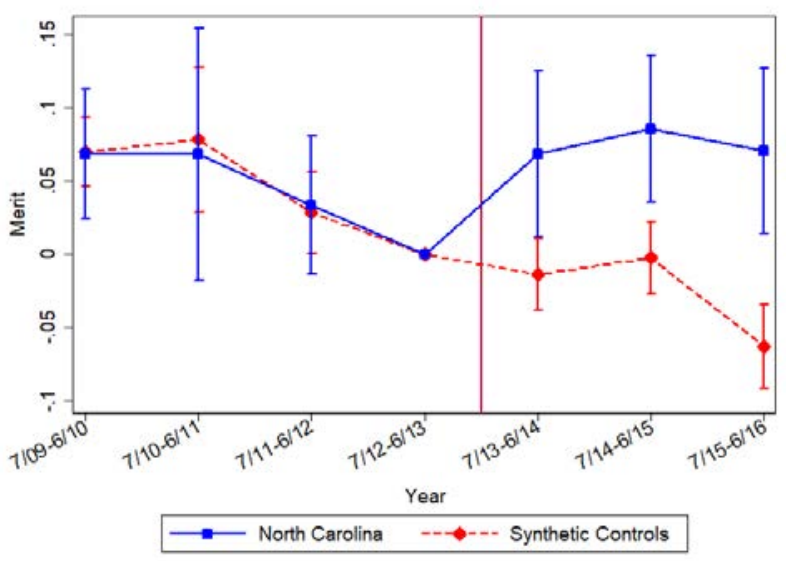

(b)

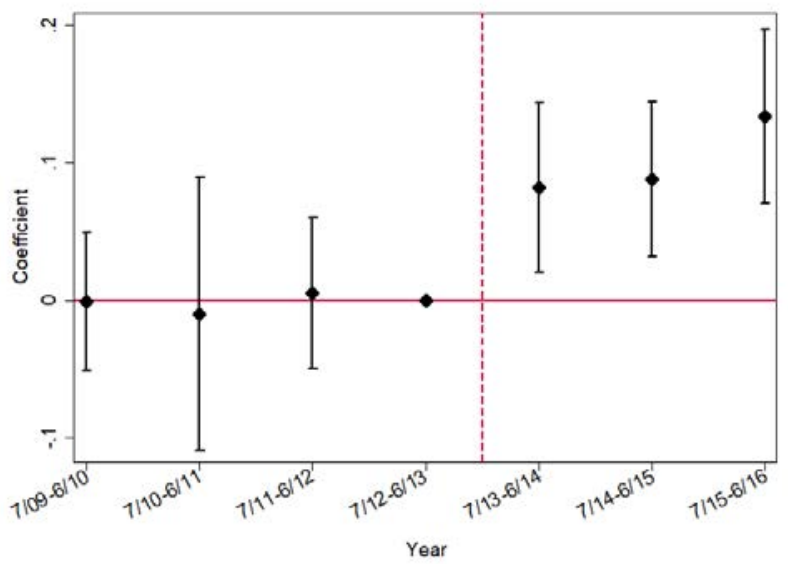

(d)

Figure 5: Selectivity of Sexual Harassment Charges for North Carolina versus Controls

The top panel reports raw averages, while the bottom panel reports event-study coefficients. Merit is the fraction of charges determined to have merit by the EEOC, normalized to 0 in the year prior to the reform. Vertical bars denote 95\% confidence intervals. See Figure 2 for the list of Other Southern States. Synthetic weights are constructed by matching on the state female unemployment rate using both pre-reform state female unemployment rate and the extra predictors of the overall state unemployment rate, state female employment to population ratio, the state female labor force participation rate, and state-industry employment weights. Note that this approach does not match on the outcome variable of merit, or use merit to predict state female unemployment rates. Weights can be found in column (1) of Appendix Table A4. 


\section{Tables}

Table 1: Summary Statistics by Claim Type

\begin{tabular}{lcc}
\hline \hline & Sexual Harassment & No Sexual Harassment \\
\hline Resolutions by Type & & \\
Merit & 0.270 & 0.186 \\
Settlement with benefits & 0.114 & 0.093 \\
Withdrawal with benefits & 0.059 & 0.049 \\
Reasonable cause & 0.096 & 0.038 \\
$\quad$ Successful conciliation & 0.029 & 0.014 \\
Unsuccessful conciliation & 0.067 & 0.030 \\
Case Characteristics & & \\
Employer retaliation involved & & \\
Employer intimidation involved & 0.634 & 0.307 \\
Legal representation & 0.057 & 0.027 \\
Worker Characteristics & 0.130 & 0.079 \\
Female & & \\
Age & & 0.519 \\
White & 0.839 & 44.6 \\
Black & 36.4 & 0.402 \\
Selected Firm Characteristics & 0.541 & 0.439 \\
Accommodation \& Food Services & 0.258 & \\
Retail & & 0.134 \\
Manufacturing & 0.138 & 0.084 \\
Health Care \& Social Assistance & 0.134 & \\
Public Administration & 0.125 & 0.100 \\
\hline Charges & 0.070 & \\
\hline \hline
\end{tabular}

Data are from EEOC Charge Database, 2000-2015. 
Table 2: Establishment Characteristics using Linked Data

\begin{tabular}{lcc}
\hline \hline & $\begin{array}{c}\text { Any Sexual } \\
\text { Harassment Charges }\end{array}$ & $\begin{array}{c}\text { No Sexual } \\
\text { Harassment Charges }\end{array}$ \\
\hline Demographics & & \\
Male & 0.538 & 0.510 \\
\% Managers Male & 0.654 & 0.604 \\
\% Female Laborers & 0.028 & 0.015 \\
\% Female Service Workers & 0.090 & 0.082 \\
White & 0.625 & 0.691 \\
Black & 0.182 & 0.125 \\
Size & & \\
Employees & & \\
Plants within Firm & 497.1 & 103.3 \\
Selected Industries & 428.1 & 758.7 \\
Manufacturing & & \\
Retail & & 0.118 \\
Health Care \& Social Assistance & 0.193 & 0.213 \\
Accommodation \& Food Services & 0.171 & 0.119 \\
Admin Support/Waste Management & 0.123 & 0.085 \\
Census Region & 0.111 & 0.052 \\
Midwest & 0.081 & \\
Northeast & & 0.234 \\
South & & 0.171 \\
West & 0.254 & 0.381 \\
\hline Establishment-years & 0.131 & 0.214 \\
\hline \hline
\end{tabular}

Establishment characteristics based on whether at least one employee filed an sexual harassment charge against their company in an establishment-year. Data links individual sexual harassment charges (the EEOC Charge data) with the characteristics of each establishment against which the charges are filed (the EEO-1 files) from 2000-2015. 
Table 3: Unemployment and the Quality of Sexual Harassment Charges

\begin{tabular}{|c|c|c|c|c|}
\hline \multirow[b]{2}{*}{ Dep var $=\mathbb{1}$ (merit) } & \multicolumn{2}{|c|}{ State x Industry Variation } & \multicolumn{2}{|c|}{ State Variation } \\
\hline & $\begin{array}{l}\text { All } \\
(1)\end{array}$ & $\begin{array}{l}\text { Retaliatory } \\
(2)\end{array}$ & $\begin{array}{l}\text { All } \\
(3)\end{array}$ & $\begin{array}{c}\text { Retaliatory } \\
(4)\end{array}$ \\
\hline$\#$ unemployed $_{j s t}{ }^{\dagger}$ & $\begin{array}{c}19.9^{* * *} \\
(6.87)\end{array}$ & $\begin{array}{c}29.6^{* * *} \\
(8.34)\end{array}$ & & \\
\hline$\#$ unemployed $_{s t}^{\dagger}$ & & & $\begin{array}{c}4.58^{* * *} \\
(1.68)\end{array}$ & $\begin{array}{l}4.71^{* *} \\
(1.89)\end{array}$ \\
\hline female & $\begin{array}{c}0.054^{* * *} \\
(0.006)\end{array}$ & $\begin{array}{c}0.057^{* * *} \\
(0.006)\end{array}$ & $\begin{array}{c}0.055^{* * *} \\
(0.006)\end{array}$ & $\begin{array}{c}0.057^{* * *} \\
(0.007)\end{array}$ \\
\hline Effect of 1 pp $\uparrow$ unemp & 0.0012 & 0.0019 & 0.0026 & 0.0027 \\
\hline Mean(merit) & .270 & .267 & .270 & .267 \\
\hline$\%$ change & 0.46 & 0.71 & 0.96 & 1.02 \\
\hline Elasticity & 0.025 & 0.038 & 0.059 & 0.064 \\
\hline State, industry, month-year FEs & $\mathrm{X}$ & $\mathrm{X}$ & $\mathrm{X}$ & $\mathrm{X}$ \\
\hline $\mathrm{N}$ charges & 61,558 & 39,039 & 61,578 & 39,053 \\
\hline $\mathrm{R}^{2}$ & 0.021 & 0.023 & 0.025 & 0.028 \\
\hline \multicolumn{5}{|c|}{$\begin{array}{l}\text { Regression estimates based on equation } 4 \text { and the sample period of } 2000-2015 \text {. Bolded 'Effect } \\
\text { of } 1 \text { pp } \uparrow \text { unemp' is the implied effect of a one percentage point increase in a state-industry's } \\
\text { (or state's) monthly unemployment rate on the fraction of charges found to have had merit by } \\
\text { the EEOC. Additional controls include an individual's race and age. Robust standard errors, } \\
\text { clustered at the state level, are reported in parentheses. } \\
{ }^{\dagger} \text { Coefficients are multiplied by } 10^{-8} \\
{ }^{*} p<0.10,{ }^{* *} p<0.05,{ }^{* * *} p<0.01\end{array}$} \\
\hline
\end{tabular}


Table 4: Female Charge Quality, by \% Male and \% Male Managers using Linked Data

\begin{tabular}{|c|c|c|c|c|}
\hline Dep var $=\mathbb{1}$ (merit) & $\begin{array}{l}A l l \\
(1)\end{array}$ & $\begin{array}{l}\text { Retaliatory } \\
(2)\end{array}$ & $\begin{array}{l}A l l \\
(3)\end{array}$ & $\begin{array}{c}\text { Retaliatory } \\
\text { (4) }\end{array}$ \\
\hline$\#$ unemployed $_{j s t} \times \% \operatorname{men}_{j}^{\dagger}$ & $\begin{array}{c}9.92^{* * *} \\
(2.53)\end{array}$ & $\begin{array}{l}8.08^{* *} \\
(3.62)\end{array}$ & & \\
\hline$\#$ unemployed $_{j s t} \times \%$ male managers $_{\text {estab }}^{\dagger}$ & & & $\begin{array}{c}4.80^{* * *} \\
(1.36)\end{array}$ & $\begin{array}{l}4.04^{* *} \\
(1.63)\end{array}$ \\
\hline sd(\% men or $\%$ male mgrs. $)$ & 0.158 & 0.160 & 0.259 & 0.260 \\
\hline Effect of 1 sd $\uparrow \%$ men or $\%$ male mgrs. & 0.0010 & 0.0008 & 0.0008 & 0.0007 \\
\hline Mean(merit) & .279 & .277 & .263 & 0.265 \\
\hline$\%$ change & 0.35 & 0.29 & 0.30 & 0.25 \\
\hline State, industry, month-year FEs & $\mathrm{X}$ & $\mathrm{X}$ & $\mathrm{X}$ & $\mathrm{X}$ \\
\hline $\mathrm{N}$ charges & 51,286 & 32,730 & 23,424 & 15,748 \\
\hline $\mathrm{R}^{2}$ & 0.021 & 0.026 & 0.024 & 0.031 \\
\hline
\end{tabular}

Regressions mirror those in Table 3 and are based on the sample period of 2000-2015. Data links individual sexual harassment charges (the EEOC Charge data) with the characteristics of each establishment against which the charges are filed (the EEO-1 files) from 2000-2015. Bolded 'Effect of 1 sd $\uparrow \%$ men or \% male mgrs.' is the implied effect of a one percentage point increase in a state-industry's monthly unemployment rate interacted with the $\%$ of men in an industry or $\%$ of male managers in an establishment on the fraction of charges found to have had merit by the EEOC. Additional controls include an individual's race and age, the number of unemployed, and the $\%$ men or the $\%$ male managers. Robust standard errors, clustered at the state level, are reported in parentheses.

$\dagger$ Coefficients are multiplied by $10^{-7}$

${ }^{*} p<0.10,{ }^{* *} p<0.05,{ }^{* * *} p<0.01$ 
Table 5: North Carolina UI Reform and the Quality of Sexual Harassment Charges

\begin{tabular}{|c|c|c|c|c|}
\hline \multirow[b]{3}{*}{ Dep var $=$ UI recipiency rate $_{s t}$} & \multicolumn{4}{|c|}{ Panel A: First Stage } \\
\hline & \multicolumn{2}{|c|}{$\begin{array}{l}\text { Other Southern } \\
\text { States as Controls }\end{array}$} & \multicolumn{2}{|c|}{$\begin{array}{c}\text { Synthetic Controls } \\
\text { Matching on Female } \\
\text { Unemployment Rate }\end{array}$} \\
\hline & $(1)$ & $(2)$ & $(3)$ & $(4)$ \\
\hline North Carolina $\times$ post & $\begin{array}{c}-0.198^{* * *} \\
(0.003)\end{array}$ & \multicolumn{3}{|c|}{$\begin{array}{c}-0.183^{* * *} \\
(0.002)\end{array}$} \\
\hline Dep mean NC pre-reform & .460 & \multicolumn{3}{|c|}{.460} \\
\hline State and month-year FEs & $\mathrm{X}$ & \multicolumn{3}{|c|}{$\mathrm{X}$} \\
\hline $\mathrm{N}$ charges & 8,792 & \multicolumn{3}{|c|}{8,845} \\
\hline $\mathrm{R}^{2}$ & 0.812 & \multicolumn{3}{|c|}{0.914} \\
\hline \multirow[b]{2}{*}{ Dep var $=\mathbb{1}$ (merit $)$} & \multicolumn{4}{|c|}{ Panel B: Reduced Form and IV } \\
\hline & Reduced Form & IV & Reduced Form & IV \\
\hline North Carolina $\times$ post & $\begin{array}{c}0.070^{* * *} \\
(0.024)\end{array}$ & & $\begin{array}{c}0.081^{* * *} \\
(0.020)\end{array}$ & \\
\hline UI recipiency rate $_{s t}$ & & $\begin{array}{c}-0.352^{* * *} \\
(0.131)\end{array}$ & & $\begin{array}{c}-0.445^{* * *} \\
(0.127)\end{array}$ \\
\hline Dep mean NC pre-reform & .211 & .211 & .211 & .211 \\
\hline$\%$ change & 33.0 & & 38.5 & \\
\hline State and month-year FEs & $\mathrm{X}$ & $\mathrm{X}$ & $\mathrm{X}$ & $\mathrm{X}$ \\
\hline $\mathrm{N}$ charges & 8,792 & 8,792 & 8,845 & 8,845 \\
\hline $\mathrm{R}^{2}$ & 0.014 & 0.012 & 0.024 & 0.021 \\
\hline
\end{tabular}

See Table 2 for the list of Other Southern States and column (1) of Appendix Table A4 for the set of synthetic control weights. Sample period is from July of 2009 through September of 2016. Robust standard errors, clustered at the state-year level, are reported in parentheses.

${ }^{*} p<0.10,{ }^{* *} p<0.05,{ }^{* * *} p<0.01$ 


\title{
11 Online Appendix Figures and Tables
}

\author{
"Why is Sexual Harassment Underreported? \\ The Value of Outside Options Amid the Threat of Retaliation"
}

By Gordon B. Dahl and Matthew Knepper 


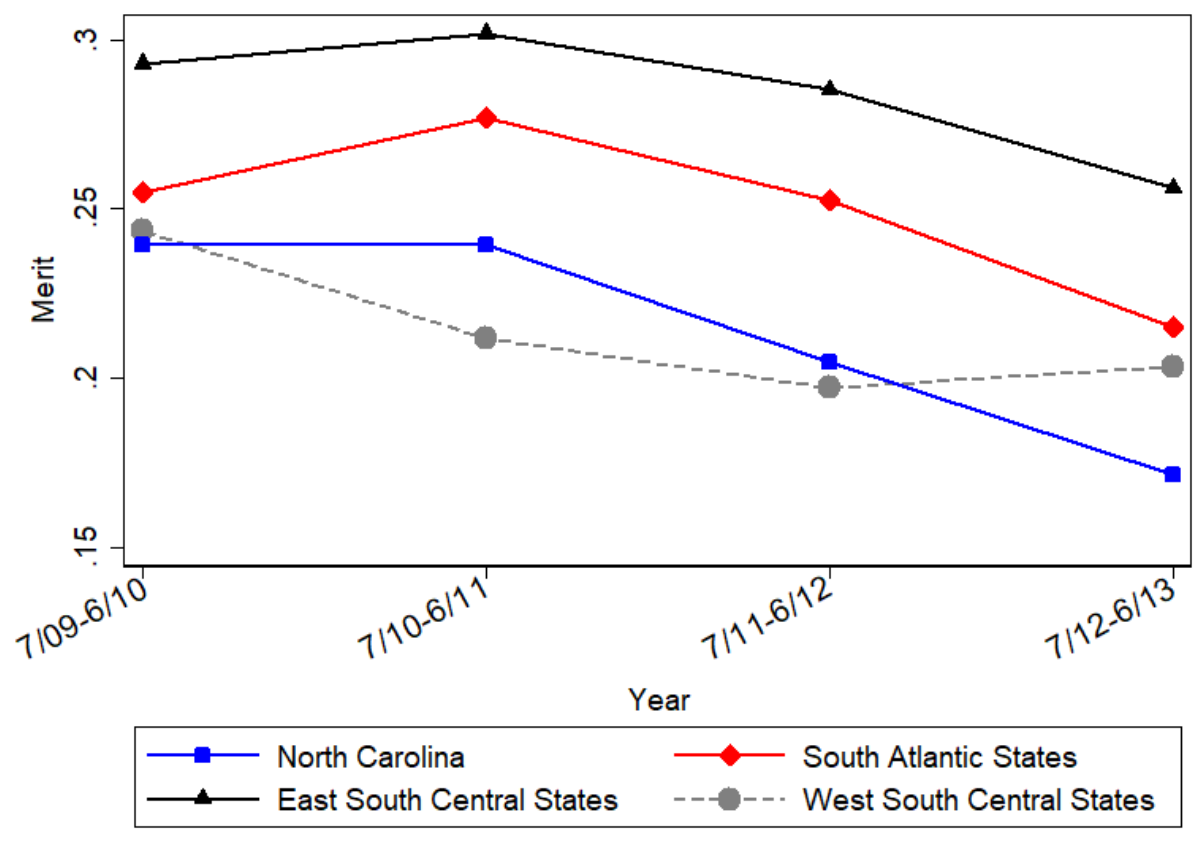

Figure A1: Merit Pre-trends in North Carolina versus each Southern Census Division

Nontreated states in the South Atlantic Census Division are Delaware, the District of Columbia, Maryland, Virginia, and West Virginia. Nontreated states in the East South Central Census Division are Alabama, Kentucky, Mississippi, and Tennessee. Nontreated states in the West South Central Census Division are Louisiana, Oklahoma, and Texas. Four Southern states which changed their UI programs are excluded (Arkansas, Florida, Georgia, South Carolina). 


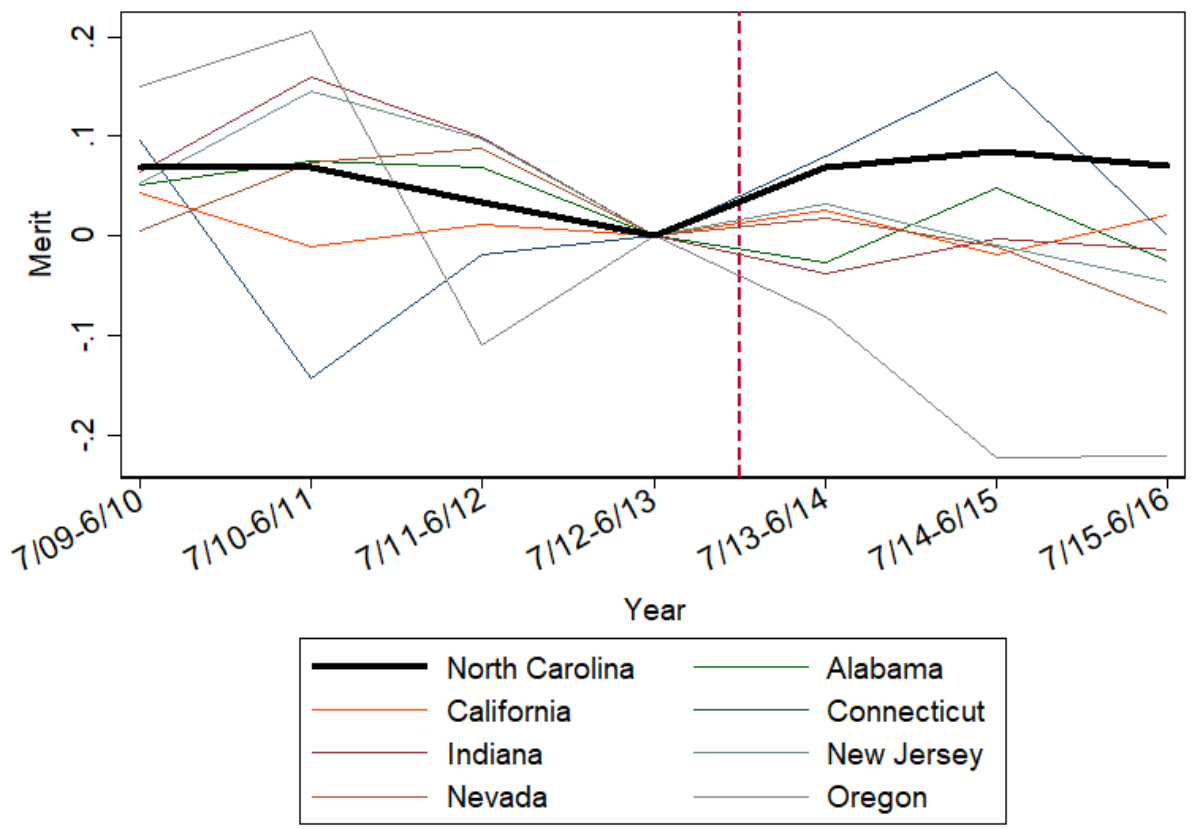

Figure A2: Merit in North Carolina versus each Synthetic Control State

Weights for each synthetic control state are found in column (1) of Appendix Table A4. 


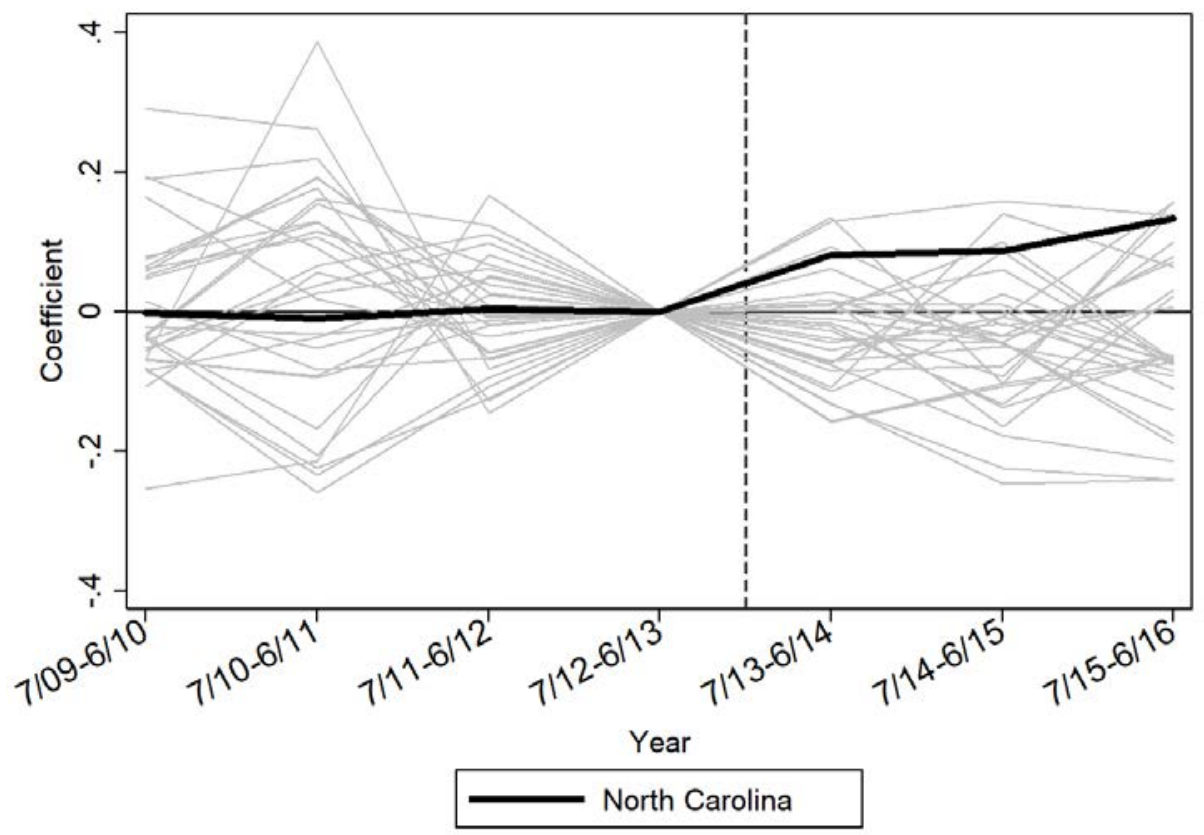

Figure A3: Merit Gaps in North Carolina and Placebo States

Light gray merit gaps represent the coefficients for each placebo state relative to its synthetic control. North Carolina's merit gap is shown in black. 


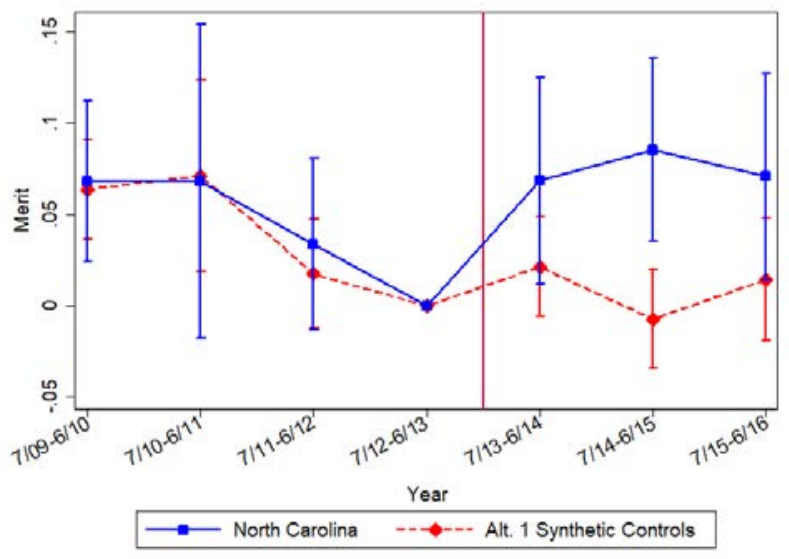

(a)

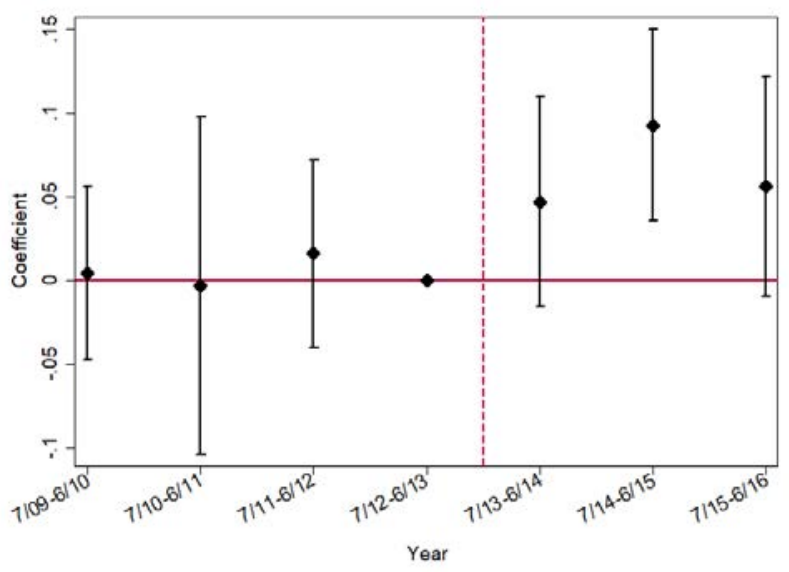

(c)

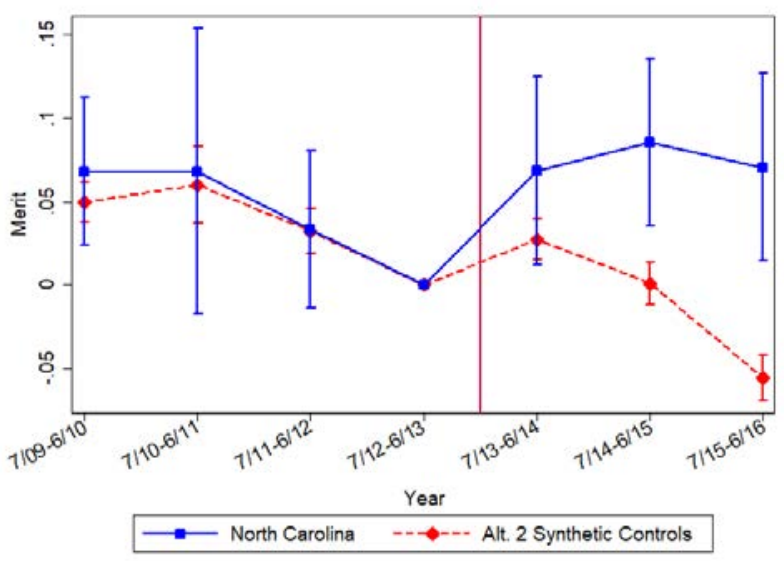

(b)

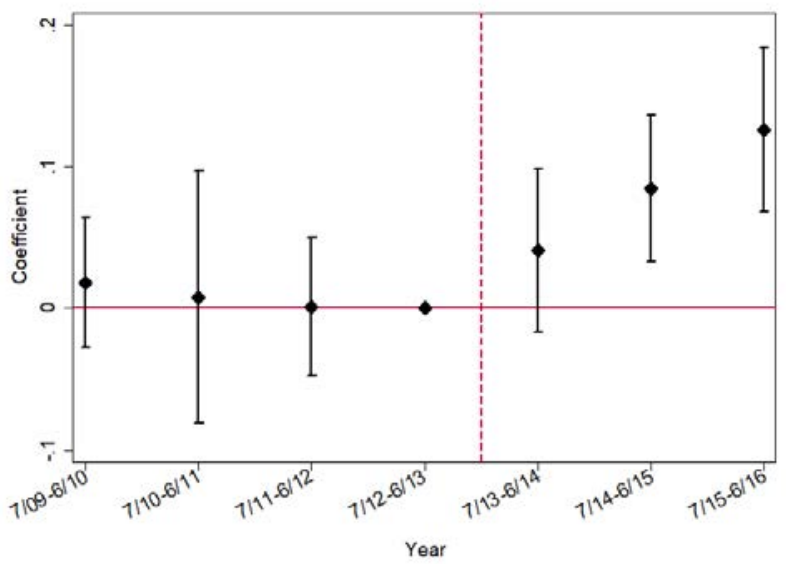

(d)

Figure A4: Event-studies Using Two Different Alternative Synthetic Controls

See notes to Figure 5. Vertical bars denote $95 \%$ confidence intervals. The first column (Alt. 1 Synthetic Controls) mirrors the approach of Figure 5 but adds merit as a predictor variable. The second column (Alt. 2 Synthetic Controls) instead matches on the outcome variable of merit using state unemployment and merit as predictor variables. 
Table A1: Alternative Measures of Labor Market Tightness

\begin{tabular}{|c|c|c|c|c|}
\hline Dep var $=\mathbb{1}($ merit $)$ & $\begin{array}{l}A l l \\
(1)\end{array}$ & $\begin{array}{c}\text { Retaliatory } \\
(2)\end{array}$ & $\begin{array}{l}A l l \\
(3) \\
\end{array}$ & $\begin{array}{c}\text { Retaliatory } \\
(4)\end{array}$ \\
\hline${\text { unemployment } \text { rate }_{j s t}}$ & $\begin{array}{l}0.289^{* * *} \\
(0.0906)\end{array}$ & $\begin{array}{l}0.269^{* * *} \\
(0.0963)\end{array}$ & & \\
\hline employment:population $_{j s t}$ & & & $\begin{array}{c}-0.568^{* * *} \\
(0.167)\end{array}$ & $\begin{array}{c}-0.368^{* *} \\
(0.180)\end{array}$ \\
\hline female & $\begin{array}{c}0.0480^{* * *} \\
(0.0052)\end{array}$ & $\begin{array}{c}0.0478^{* * *} \\
(0.0071)\end{array}$ & $\begin{array}{c}0.0478^{* * *} \\
(0.0052)\end{array}$ & $\begin{array}{c}0.0474^{* * *} \\
(0.0072)\end{array}$ \\
\hline Effect of $1 \mathrm{pp} \uparrow$ & 0.0029 & 0.0027 & -0.0057 & -0.0037 \\
\hline Mean(merit) & .270 & .267 & .270 & .267 \\
\hline$\%$ change & 1.07 & 1.00 & -2.10 & -1.36 \\
\hline Elasticity & 0.067 & 0.063 & -0.134 & -0.087 \\
\hline State, industry, month-year FEs & $\mathrm{X}$ & $\mathrm{X}$ & $\mathrm{X}$ & $\mathrm{X}$ \\
\hline $\mathrm{N}$ charges & 61,450 & 38,981 & 61,450 & 38,981 \\
\hline $\mathrm{R}^{2}$ & 0.0218 & 0.0248 & 0.0220 & 0.0249 \\
\hline
\end{tabular}

These regressions mirror those in Table 3, but instead of using the number unemployed, they use the unemployment rate or employment to population ratio. Robust standard errors, clustered at the state level, are reported in parentheses.

${ }^{*} p<0.10,{ }^{* *} p<0.05,{ }^{* * *} p<0.01$ 
Table A2: Multinomial Logit Model (Baseline Outcome $=$ No Merit)

\begin{tabular}{lcc}
\hline \hline Panel A: Outcome $=$ Settlement & $\begin{array}{c}\text { All } \\
(1)\end{array}$ & $\begin{array}{c}\text { Retaliatory } \\
(2)\end{array}$ \\
\hline $1 \%$ increase in unemployed $_{j s t}$ & $0.0053^{* * *}$ & $0.0052^{* *}$ \\
& $(0.0020)$ & $(0.0024)$ \\
\hline Panel B: Outcome $=$ Reasonable Cause & & \\
\hline & & \\
$1 \%$ increase in unemployed $_{j s t}$ & 0.0038 & $0.0091^{* * *}$ \\
& $(0.0029)$ & $(0.0033)$ \\
\hline state, industry, month-year FEs & $\mathrm{X}$ & $\mathrm{X}$ \\
$\chi^{2}$ test for joint significance & 12.78 & 17.19 \\
p-value & 0.0017 & 0.0002 \\
N charges & 61,558 & 39,039 \\
\hline \hline
\end{tabular}

Estimates are reported as marginal effects for a $1 \%$ increase in unemployment $(6,230)$, evaluated at the mean number of unemployed in a state-industry-month $(33,546)$. The $\chi^{2}$ test refers to the null hypothesis that the 2 coefficients are jointly zero. Additional controls include an individual's sex, race, and age. The sample period spans 2000-2015. Robust standard errors, clustered at the state level, are reported in parentheses.

${ }^{*} p<0.10,{ }^{* *} p<0.05,{ }^{* * *} p<0.01$ 
Table A3: Unemployment and the Volume of Sexual Harassment Charges

\begin{tabular}{|c|c|c|c|c|}
\hline \multirow[b]{2}{*}{ Dep var $=\#$ of charges } & \multicolumn{2}{|c|}{ State $\mathrm{x}$ Industry variation } & \multicolumn{2}{|c|}{ State variation } \\
\hline & $\begin{array}{l}\text { All } \\
(1)\end{array}$ & $\begin{array}{c}\text { Retaliatory } \\
(2)\end{array}$ & $\begin{array}{l}\text { All } \\
(3)\end{array}$ & $\begin{array}{c}\text { Retaliatory } \\
(4)\end{array}$ \\
\hline \# unemployed ${ }_{j s t}$ & $\begin{array}{c}2.91 \\
(2.27)\end{array}$ & $\begin{array}{l}2.46^{*} \\
(1.47)\end{array}$ & & \\
\hline \# unemployed $_{s t}$ & & & $\begin{array}{l}2.75^{* *} \\
(1.21)\end{array}$ & $\begin{array}{c}3.60^{* * *} \\
(1.05)\end{array}$ \\
\hline Effect of $1 \mathrm{pp} \uparrow$ & 4.40 & 3.72 & 4.15 & 5.44 \\
\hline mean(\# national charges) & 667.7 & 428.0 & 667.7 & 428.0 \\
\hline$\%$ change & 0.66 & 0.86 & 0.62 & 1.27 \\
\hline Elasticity & 0.042 & 0.055 & 0.039 & 0.080 \\
\hline State, Industry, Time FEs & $\mathrm{X}$ & $\mathrm{X}$ & $\mathrm{X}$ & $\mathrm{X}$ \\
\hline labor force size (thous.) & 151,055 & 151,055 & 151,055 & 151,055 \\
\hline N (cells) & 120,906 & 120,906 & 9,985 & 9,985 \\
\hline $\mathrm{R}^{2}$ & 0.409 & 0.353 & 0.884 & 0.872 \\
\hline
\end{tabular}

These regressions mirror those in Table 3, but use the number of charges filed as the dependent variable. Regression coefficients estimate the change in charges filed for 1,000,000 person increase in the number unemployed. Observations are weighted by the industry share of employment in each state's labor force in columns (1) and (2) and by the state labor force size in columns (3) and (4). Bolded 'Effect of $1 \mathrm{pp} \uparrow$ ' is the implied effect of a one percentage point increase in the national unemployment rate on the national monthly number of sexual harassment charges filed. Robust standard errors, clustered at the state level, are reported in parentheses.

${ }^{*} p<0.10,{ }^{* *} p<0.05,{ }^{* * *} p<0.01$ 
Table A4: Synthetic Control Weights

\begin{tabular}{lccc}
\hline \hline State & $(1)$ & $(2)$ & $(3)$ \\
\hline Alaska & 0 & 0 & 0.021 \\
Alabama & 0.479 & 0 & 0.016 \\
Arizona & 0 & 0.135 & 0.019 \\
California & 0.046 & 0.194 & 0.018 \\
Colorado & 0 & 0 & 0.011 \\
Connecticut & 0.107 & 0 & 0.016 \\
DC & 0 & 0 & 0.014 \\
Delaware & 0 & 0 & 0.012 \\
Hawaii & 0 & 0 & 0.008 \\
Iowa & 0 & 0.05 & 0.102 \\
Idaho & 0 & 0 & 0.01 \\
Indiana & 0.003 & 0 & 0.018 \\
Kentucky & 0 & 0.20 & 0.017 \\
Louisiana & 0 & 0 & 0.011 \\
Massachusetts & 0 & 0 & 0.011 \\
Maryland & 0 & 0 & 0.011 \\
Minnesota & 0 & 0 & 0.008 \\
Mississippi & 0 & 0 & 0.016 \\
North Dakota & 0 & 0 & 0.002 \\
Nebraska & 0 & 0 & 0 \\
New Jersey & 0.083 & 0 & 0.02 \\
New Mexico & 0 & 0 & 0.012 \\
Nevada & 0.099 & 0.292 & 0.485 \\
New York & 0 & 0 & 0.013 \\
Ohio & 0 & 0 & 0.015 \\
Oklahoma & 0 & 0 & 0.008 \\
Oregon & 0.183 & 0.029 & 0.015 \\
Pennsylvania & 0 & 0 & 0.011 \\
Tennessee & 0 & 0 & 0.014 \\
Texas & 0 & 0 & 0.011 \\
Utah & 0 & 0 & 0.009 \\
Virginia & 0 & 0 & 0.008 \\
Washington & 0 & 0 & 0.014 \\
Wisconsin & 0 & 0 & 0.012 \\
West Virginia & 0 & 0.10 & 0.014 \\
\hline In column (1), weights are determined by match- \\
ing on state female unemployment rate in the \\
pre-period using & state & female unemployment \\
rate, overall state & unemployment rate, state fe- \\
male employment:population, state female labor \\
force participation rate, and state-industry em- \\
ployment weights. & In column $(2)$ weights are de- \\
termined by matching on the same covariates as \\
in column (1), except we add merit as an addi- \\
tional predictor variable. & In column \\
are determined by & matching & on merit in the pre- \\
period using only state unemployment and merit \\
as predictor variables. & & \\
& & &
\end{tabular}

